\title{
Physiological Responses to Drought, Salinity, and Heat Stress in Plants: A Review
}

\author{
Tiago Benedito dos Santos ${ }^{1, *(\mathbb{C}}$, Alessandra Ferreira Ribas ${ }^{1}{ }^{\mathbb{D}}$, Silvia Graciele Hülse de Souza ${ }^{2}$, \\ Ilara Gabriela Frasson Budzinski ${ }^{3}$ (i) and Douglas Silva Domingues ${ }^{3}$ (i)
}

1 Graduate Program in Agronomy, Universidade do Oeste Paulista (UNOESTE), Presidente Prudente 19067-175, SP, Brazil; alessandra_ribas@hotmail.com

2 Postgraduate Program in Biotechnology Applied to Agriculture, Universidade Paranaense (UNIPAR), Umuarama 87502-210, PR, Brazil; silviahulse@prof.unipar.br

3 Group of Genomics and Transcriptomes in Plants, Department of Biodiversity, Institute of Biosciences, Universidade Estadual Paulista (UNESP), São Paulo State University, Rio Claro 13506-900, SP, Brazil; ilarafrass@gmail.com (I.G.F.B.); doug@rc.unesp.br (D.S.D.)

* Correspondence: tiagobio02@yahoo.com.br

check for

updates

Citation: dos Santos, T.B.; Ribas, A.F.; de Souza, S.G.H.; Budzinski, I.G.F.; Domingues, D.S. Physiological Responses to Drought, Salinity, and Heat Stress in Plants: A Review. Stresses 2022, 2, 113 -135. https:/ / doi.org/10.3390/stresses2010009

Academic Editors: Marcello Iriti, Georgios Liakopoulos and Eleni Tani

Received: 31 December 2021 Accepted: 14 February 2022 Published: 16 February 2022

Publisher's Note: MDPI stays neutral with regard to jurisdictional claims in published maps and institutional affiliations.

Copyright: (C) 2022 by the authors. Licensee MDPI, Basel, Switzerland. This article is an open access article distributed under the terms and conditions of the Creative Commons Attribution (CC BY) license (https:// creativecommons.org/licenses/by/ $4.0 /)$.

\begin{abstract}
On the world stage, the increase in temperatures due to global warming is already a reality that has become one of the main challenges faced by the scientific community. Since agriculture is highly dependent on climatic conditions, it may suffer a great impact in the short term if no measures are taken to adapt and mitigate the agricultural system. Plant responses to abiotic stresses have been the subject of research by numerous groups worldwide. Initially, these studies were concentrated on model plants, and, later, they expanded their studies in several economically important crops such as rice, corn, soybeans, coffee, and others. However, agronomic evaluations for the launching of cultivars and the classical genetic improvement process focus, above all, on productivity, historically leaving factors such as tolerance to abiotic stresses in the background. Considering the importance of the impact that abiotic stresses can have on agriculture in the short term, new strategies are currently being sought and adopted in breeding programs to understand the physiological, biochemical, and molecular responses to environmental disturbances in plants of agronomic interest, thus ensuring the world food security. Moreover, integration of these approaches is bringing new insights on breeding. We will discuss how water deficit, high temperatures, and salinity exert effects on plants.
\end{abstract}

Keywords: climate extremes; agriculture; abiotic stress; physiological strategies; expression genes

\section{Introduction}

Nowadays, the increase in temperatures as a result of global warming and other factors is already a reality. This scenario represents one of the main challenges posed to the scientific community today. Agriculture is highly dependent on climatic conditions; therefore, it may suffer a great impact if no measures are taken to adapt and mitigate agricultural systems. Among the abiotic stresses, drought, salinity, extreme temperatures, chemical pollutants, nutritional deficiency, and oxidative stress stand out as the main environmental restrictions modern agriculture faces. These are factors that compromise development and growth, in addition to influencing the morphological, physiological, biochemical, and molecular processes of plants [1]. Plant responses to abiotic stresses have been the subject of numerous studies worldwide. Initially, they were carried out on model plants and, later, on several economically important crops such as rice, corn, soybeans, coffee, and others. However, agronomic evaluations for the launching of cultivars and the classical genetic improvement process focus, above all, on productivity, historically leaving factors such as tolerance to abiotic stresses in the background. Considering the importance of the impact that abiotic stresses can have on agriculture, new strategies have been sought in breeding programs to understand the physiological, biochemical, and 
molecular responses to environmental disturbances in agronomic plants. For example, we researchers are faced with the growing need to understand the genes present in important regulatory pathways that can be introgressed in breeding programs, aiming to increase and help the plant tolerate different abiotic stresses. We will discuss how water deficit, high temperatures, and salinity exert effects on plants.

\section{Response Mechanism to Abiotic Stresses in Plants}

Plants are often exposed to different situations of abiotic stresses. In evolutionary terms, adapted organisms are those that have managed to modulate several response mechanisms in favor of their defense in order to overcome such stresses and return to normal basal metabolism. Importantly, these environmental factors severely limit agricultural growth and productivity. As an example, the increase in atmospheric $\mathrm{CO}_{2}$ can trigger changes in the photosynthetic rate of plants, causing changes in the growth rate, which usually impacts positively overall biomass, but decreasing nutritional quality $[2,3]$. Plants respond to stimuli caused by stress with distinct changes related to their development and physiology. In this context, many mechanisms like photosynthesis and gas exchange [4,5], cell death, changes in cell wall composition [6], nutrient translocation [7], transcriptional activity of genes, transposable elements [8], lipid signaling [9], metabolites, proteins [10], and antioxidant profile [11] can be changed during stresses.

The physiological response mechanism for abiotic stresses occurs from a complex pathway of responses, starting with the perception of stress, which triggers a cascade of molecular events, ending at various levels of physiological, metabolic, and developmental responses [12]. These are summarized in Figure 1.

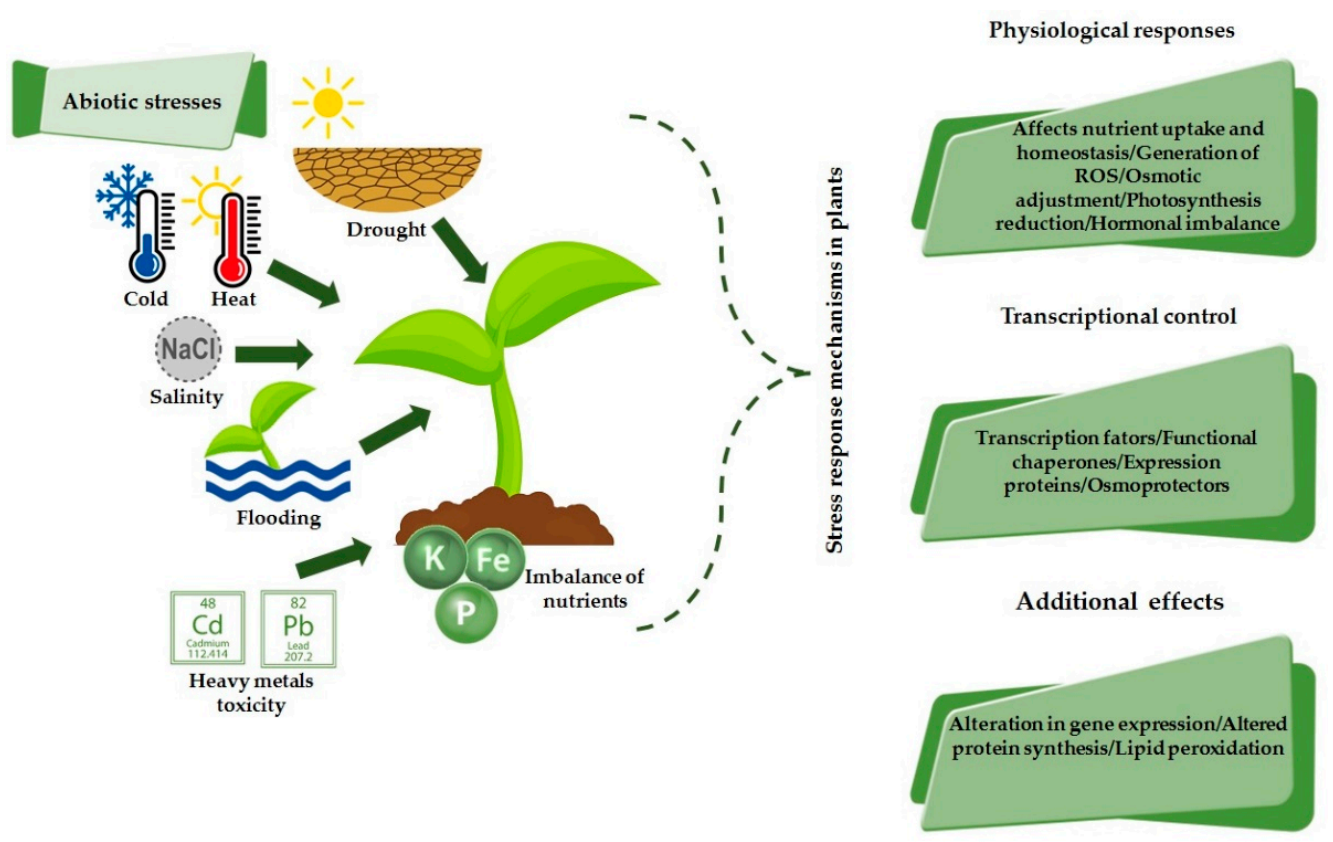

Figure 1. Plant response cascade to different abiotic stresses.

With the perception of these imbalances induced by the abiotic stresses listed above, plants redirect their energy and nutrients to reproduction and defense mechanisms, causing a decrease in the growth rate that results in lower biomass production.

\section{Water Deficit in Plants}

Due to the ongoing climate change scenario and the rising human population, water availability is a crucial issue for agriculture, the world's largest water user, accounting for more than $70 \%$ of global withdrawals [13]. Irrigated agriculture covers $20 \%$ of world cultivated lands and accounts for $40 \%$ of global food output. On average, irrigated agri- 
culture is at least twice as productive per unit of land as rainfed agriculture [13]. Water normally represents from 50 to $90 \%$ of plants' fresh weight. The majority of water content $(60-90 \%)$ is located within cells, and the rest is mainly in cell walls [14]. In this scenario, the maintenance of growth and crop productivity under adverse environmental stress conditions such as water deficit represents one of the main challenges of modern agriculture [15]. Water deficit occurs when the plant water requirement cannot be fully satisfied (e.g., through enough precipitation or irrigation), and the plant's normal functioning is affected (e.g., growth, photosynthesis rate, stomatal conductance). In other words, water deficit occurs when the transpiration rate from the leaf surface is higher than the water uptake by roots. This imbalance between water uptake and water loss is related to a lower soil water potential than the roots [16]. Several factors can cause plant water deficit, including inadequate precipitation, high evaporative demand, decreased groundwater level, and water retention by soil particles [14,17]. This period of abnormally dry weather, resulting in soil-water deficit and subsequently plant water deficit, is defined as drought, a major abiotic stress that negatively influences crop production and yield [18]. The impacts of drought on agriculture are aggravated due to the depletion of water resources, increased food demand, and climate changes [19]. These have become the most important limiting factors to crop productivity and ultimately to food security, increasing the pressure on agriculture to use water more efficiently. As such, agricultural water consumption, water use efficiency (WUE), and the development of drought-tolerant plants are crucial for improving crops. WUE is defined as the amount of carbon assimilated as biomass or grain produced per unit of water used by the crop [20]. It determines the plant's ability to cope with moderate or severe soil water deficit, representing a major factor in plant survival under drought stress [21]. Increasing the WUE of crops constitutes a major goal of breeding and genetic engineering efforts [22]. Using QTL analysis, Damerum et al. (2021) [23] identified genomic regions controlling WUE in wild and cultivated lettuce under well-watered and droughted conditions. QTL were detected for carbon isotope discrimination, transpiration, stomatal conductance, leaf temperature and yield, controlling $4-23 \%$ of the phenotypic variation. Candidate genes such as aquaporins, late embryogenesis abundant proteins, abscisic acid-responsive element binding protein and glutathione S-transferase were found in this region associated with WUE [23]. Jia et al. (2021) [24] showed that the overexpression of MdATG8i-OE (autophagy protein) gene in apple resulted in plants exhibiting higher WUE than wild-type under long-term moderate drought conditions.

Since the last century, several attempts have been made to improve and/or generate drought-tolerant plants. To achieve this goal, different techniques have been used, from plant breeding to the production of transgenic lines, as well as the use of precise genome editing methods and omics approaches.

The employment of plant breeding methods has an enormous potential to accelerate drought-tolerant plant production, and considerable progress has been made in this direction in different crops such as barley [25,26] soybean [27], popcorn [28,29], rice [30,31], wheat $[32,33]$. However, developing drought-tolerant plants through breeding is restricted by a narrow genetic pool, low heritability of drought tolerance/resistance, the complexity involved in tolerance, and the extent of environmental interactions [34].

In contrast, identifying and characterizing drought-related molecules by omics techniques (i.e., genomics, transcriptomics, proteomics, and metabolomics) has opened great opportunities for crop improvement. By combining molecular and physiological analysis, Chevilly et al. (2021) [35] characterized the drought response of two broccoli cultivars (drought-sensitive and drought-tolerant). The authors found increased levels of methionine and abscisic acid in drought-tolerant cultivars while urea, quinic acid, and gluconic acid lactone levels decreased. In a multi-omics and functional characterization analysis Mehari et al. (2021) [36] found that the gene Gh_A06G1257 (GhALDH7B4), belonging to the aldehyde dehydrogenase family, plays a role in drought tolerance. The authors also found that the amino acids valine, glutarate, proline, glutamate, and tryptophan were the most significant metabolites playing roles in drought stress tolerance [36]. Nevertheless, 
in practical terms, generating genetically modified plants is an arduous and demanding task requiring complex and expensive laboratory methods [17]. Drought is a multidimensional stress factor, and its effects on plants are complex. As a result, there are still many gaps at the molecular and physiological levels regarding the molecular-to-physiological mechanisms underlying plant responses to drought.

\subsection{Strategies to Combat the Water Deficit}

As sessile organisms, plants are exposed to several adverse factors in natural environments. Water deficit, for example, can trigger a negative impact on plant growth and development, compromising its yield. Plants have evolved numerous adaptation and acclimation strategies at different levels, ranging from morphology and anatomical structures to physiological and biochemical reactions, aiming to preserve their hydric status [37]. The extension of plant responses depends on the length and severity of water deficiency and its species, age, and developmental stage. Regardless of the temporary nature of the stress, the plant's set of properties and vital functions gradually decrease according to its duration [38]. Moderate water deficit causes significant morphological and physiological alterations, while severe deficit may lead to plant death [39]. Drought resistance refers to the ability of plants to survive or grow in a harsh environment caused by drought stress conditions. This capability is a sophisticated trait related to adaptations at different levels, which allow plants to adapt to specific habitats for the benefit of their growth and development [38]. Drought resistance mechanisms in plants can be classified into four categories: avoidance, tolerance, escape, and recovery [40]. Drought avoidance is characterized by the maintenance of high plant water potentials in the presence of water limitation. It is responsible for rearrangements in plant morphology as well as in cellular metabolism (e.g., development of deeper root systems, stomatal closure, and leaf rolling, wax accumulation on the leaf surface [41,42]. Drought tolerance relies on the ability of plants to sustain physiological activities under severe drought stress conditions through the remodeling of gene regulation and metabolic pathways to reduce or repair the resulting stress damage [40,42]. Drought escape refers to the synchronization of the plant growth period, life cycle, or planting time to prevent the growing season from encountering drought [42]. Drought recovery refers to the plant capacity to regenerate metabolism after the cessation of severe drought, which causes the complete session of growth, turgor loss, and leaf desiccation [43]. Prolonged drought conditions are associated with drought escape or avoidance, whereas short but severe drought periods induce drought tolerance [42]. As mentioned above, plants have adapted to water limitation using different strategies at different levels, from anatomical to molecular changes.

\subsection{Physiological Strategies for Increasing Productivity under Water Deficit Conditions}

Water limitation impairs normal plant growth, disturbs water relations, and reduces water-use efficiency. To cope with this condition, plants have evolved a series of morphological, physiological, and biochemical responses, including changes in photosynthesis, respiration, ion exchange, transpiration, osmotic regulation, activation of drought-induced proteins, and antioxidant enzymes.

At the morphological level, the responses of roots and leaves are crucial to reduce water loss and promote WUE. The root system plays a critical role in response to water deficit stress. Its length, weight, volume, and density are important features associated with crop drought resistance [40]. Leaf rolling is a drought-adaptive trait induced by turgor pressure that reduces water consumption under water stress. Stomata are pores allowing gas exchange between plant and environment, ensuring maximum absorption of $\mathrm{CO}_{2}$ for photosynthesis, and meanwhile controlling the optimal transpiration [40]. Plants first recognize water deficit in the soil by root cells; then, abscisic acid (ABA) is synthesized. Subsequently, ABA triggers signals to other organs and tissues through vascular bundles, causing morphological/anatomical alterations such as leaves senescence, stomatal closure, reduction of the leaf surface, induction of root to shoot ratio, and enhancing plant water 
uptake from soil by reducing the water potential contrary to the water-limiting environment through osmotic adjustments [44-46]. The ABA signaling pathway involves a cascade of receptors, phosphatases, kinases, G-proteins, proteins in the ubiquitin pathway, and transcription factors (TFs) [47]. Zhu et al. (2021) [48] found that the transcription factor ipa1 (ideal plant architecture 1) significantly improved rice drought tolerance at seedling stage mainly through activating ABA pathway. The authors have used a pair IPA1 and ipa1-near isogenic lines to obtain ipa1 plants that had a better-developed root system and smaller leaf stomatal aperture. Stomatal closure mediated by ABA can be considered a quick short-term response to water limitation. However, ROS, nitric oxide (NO), and calcium ion $\left(\mathrm{Ca}^{2+}\right)$ are known as secondary messengers involved in ABA-signaling, which can promote events that facilitate plants' long-term adaptation against biotic and abiotic stress (e.g., osmolyte accumulation, up-regulation of adaptive genes, hypersensitive response (HR), and programmed cell death (PCD)) [47]. Despite morpho-anatomical traits promoted by drought, physiological and biochemical limitations might have a greater impact on plant performance. Photosynthesis and respiration, the hubs of energy metabolism in plants, are negatively impacted by drought. Photosynthesis is one of the main processes affected by water stress as the photosynthetic and transpiration rates drop with the decrease of soil relative water content. Stomatal closure decreases leaf $\mathrm{CO}_{2}$ influx, limiting carboxylation and internal $\mathrm{CO}_{2}$ levels [49]. This lower $\mathrm{CO}_{2}$ diffusion from the environment to the carboxylation site is considered the major reason behind decreased photosynthetic rate during mild to moderate drought stress [50]. Water limitation also alters the electron transport chain (ETC), which further enhances reactive oxygen species (ROS) (e.g., superoxide, hydrogen peroxide, and hydroxyl radicals) within cell organelles, negatively affecting PSI and PSII photosystems and causing disruption of thylakoid structures. To deal with drought-induced damage on the photosynthetic apparatus, plant responses include changes in thermal dissipation of light energy, photo destruction of the D1 protein of PSII, dissociation of the light-harvesting complexes from photosynthetic reaction centers, and others [16]. Drought tolerance is a costly phenomenon for plants, as they expend an enormous amount of energy to cope with it. The root is a major consumer of carbon fixed in photosynthesis, with is used for growth and maintenance in addition to dry matter production.

Plant growth is determined by the ratio between photosynthetic $\mathrm{CO}_{2}$ assimilation and respiratory $\mathrm{CO}_{2}$ release. Modulation of the carbon metabolism of plant cells depends on the balance between photosynthesis and respiration. The respiration rate is regulated by processes that use respiratory products (adenosine triphosphate-ATP, nicotinamide adenine dinucleotid-NADH) and intermediates from the tricarboxylic acid cycle (TCA), which together contribute to plant growth. Although photosynthesis can become completely impaired under severe drought, the respiration rate may increase [51] or decrease [38]. Reduced rates of photosynthesis are likely to reduce substrate supply to mitochondria, resulting in a lower rate of foliar respiration. Alternatively, drought might increase the demand for respiratory ATP to support cellular metabolism [52].

Under drought conditions, ROS are produced in plants' mitochondria and might damage cellular components [53]. The plant mitochondrial ETC includes a non-energyconserving terminal oxidase called alternative oxidase (AOX). This pathway, as well as photorespiration, can be used by plants exposed to water deficit to maintain cell functioning by preventing ROS accumulation [54]. The TCA cycle pathway can also be modified to prevent the generation of excess reductants through the $\gamma$-aminobutyric acid (GABA) synthesis. Its accumulation occurs during stress conditions and may constitute a stress adaptive response $[55,56]$. The TCA cycle pathway can also be modified to prevent the generation of excess reductants through the $\gamma$-aminobutyric acid (GABA) synthesis. Its accumulation occurs during stress conditions and may constitute a stress adaptive response $[55,56]$. Xu et al. (2021) [57] found that GABA does not initiate changes in stomatal pore aperture, rather it antagonizes changes in pore size and, the authors proposed that cytosolic GABA signals modulate stomatal opening, WUE and drought resilience transduced through negative regulation of the ALMT9 (aluminum-activated malate transporter 9) activity. 
Plant hormones, secondary metabolites, inorganic acids, carbohydrates, amino acids, and polyamines play crucial roles in stress tolerance mechanisms. The accumulation of these compounds in plants reduces the osmotic potential and improves cell water retention in response to water stress. Their increased levels represent the plant biochemical responses to water limitation by altering membrane stabilization, osmoregulation, and ROS scavenging, reducing leaf area and ion leakage, and promoting root development [58]. An example is the amino acid proline, a key signaling moiety against drought stress, which acts as an osmoprotectant [59]. Its accumulation helps plants maintain membrane integrity through decreased lipid peroxidation by defending cell redox potential and declining ROS levels. Other amino acids have been found to have a role in drought tolerance. [35] found that drought tolerant broccoli plants presented higher levels of methionine [35]. In cotton, valine, glutarate, glutamate, tryptophan and proline accumulated under drought stress [36]. Recently, studies have indicated that exogenous application of various plant growth regulator (PGRs), such as hormones, polyamines, organic acids, antioxidants, osmoprotectants, and others improved drought resistance in crops [60-62]. These studies reported that the application of PGRs enhance parameters such as photosynthetic capacity, relative water content (RWC), gas exchange attributes and accumulation of osmolytes and antioxidants. Such priming treatment is a very promising strategy in modern crops for the development of drought resistance plants. As an example, Xie et al. 2021 [63] identified that exogenous application of citric acid in tobacco plants resulted in higher chlorophyll content, net photosynthesis, relative water content, abscisic acid content and lower stomatal conductance, transpiration, and water loss under drought conditions.

\subsection{Difficulties and Advances in the Development of Drought-Tolerant Cultivars}

Drought tolerance is not a qualitative trait, but a complex quantitative polygenic trait controlled by a large number of genes, each contributing to a small effect [64]. Furthermore, drought-tolerant cultivars suffer from high interactions between genotype and environment $(\mathrm{G} \times \mathrm{E})$, low heritability, and difficulty in mass screening of plant traits and genes $[64,65]$. This complexity explains the difficulty of understanding the molecular mechanisms triggered by drought as well as the slow progress in yield improvement in drought-prone environments. Conventional plant breeding has achieved genetically improved drought-tolerant lines/cultivars of some selected crops [66]. However, this approach is highly time-consuming and labor- and cost-intensive [67]. In recent decades, crop physiology, marker-assisted breeding, and omics have led to insights into drought tolerance mechanisms providing new knowledge and tools for plant improvement. Some of the new technologies rely on marker-assisted selection (MAS), genome-wide selection (GWAS), gene editing strategies, and omics approaches (genomics, transcriptomics, proteomics, metabolomics). Phenomics is another important strategy that has been used to improve the detection of drought-related traits by linking plant physiology with genomics through image analysis, machine vision, robotics, and computing to widen the scope of plant biology [68].

Despite the relevance of quantitative trait loci (QTL) and GWAS analysis in the identification of genomic regions for selecting drought-related alleles and identifying genetic variants associated with drought-related traits, the candidate genes through which the identified genetic variants exert their effects on traits are remained largely unknown [69]. In this respect, integrating a suite of modern breeding techniques with multi-omics platforms and high-throughput phenotyping can greatly improve the current knowledge about drought stress response in crops.

\section{Salinity}

In agriculture, land salinization has been shown to be a limiting factor in the last half-century [70]. Currently, about one-third of the world's arable area is suffering from salinization, significantly reducing crop production and yield [71]. Soil salinization is further aggravated at the global level due to poor irrigation practices, inappropriate agro- 
chemical usage, and industrial pollution [72]. In the meantime, salt concentrations, in general, can cause changes in physiological and biochemical functions, restricting the growth and development of both the aerial part and the root system of the plants. Salt causes two types of stress in plants: osmotic and ionic. High salt concentrations in the soil reduce the soil water potential, leading to reduced water uptake by plant roots [73]. On the other hand, an excessive accumulation of ions as $\mathrm{Na}^{+}$and $\mathrm{Cl}^{-}$in cells results in toxicity on the plant or nutritional disorders [74]. In this sense, it is necessary to improve management techniques to reduce the damage caused by this phenomenon and intensify studies and plant improvement programs aimed at increasing tolerance to salt stress. Agricultural land salinization poses a significant challenge for the future, given the predictions of climate change and population growth.

\subsection{Response Mechanisms to Saline Stress}

In plants subjected to salinity, an osmotic adjustment mechanism is initiated to maintain the turbidity of the cells, resulting in the slow growth of stressed plants. In the meantime, when plants are induced by salt stress, the changes triggered by it may vary according to management and genotype, developmental stage, intensity, and duration of stress [75]. Plants can trigger different physiological and biochemical mechanisms to deal with the resulting stress (Figure 2), which include: changes in morphology, anatomy, water relations, photosynthesis, hormones, ion distribution, and biochemical adaptation [76].

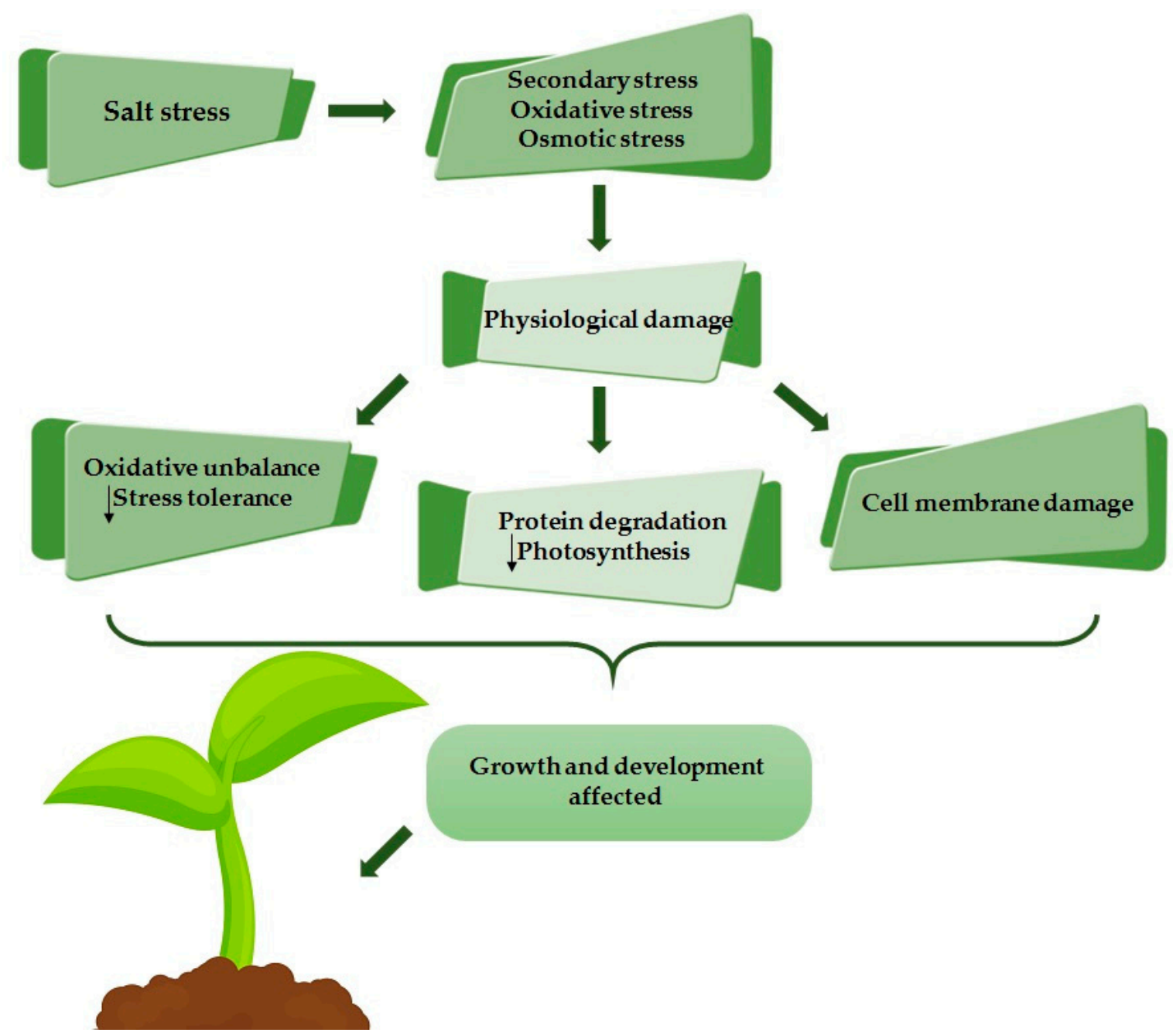

Figure 2. Some of the effects triggered by salt stress on plants. 
The response of plants to salinity comprises two main steps: (i) the first is considered rapid and is described as the osmotic phase, as the salt reaches the roots decreasing the osmotic potential of the soil-plant relationship, triggering a reduction in shoot growth due to reduced water potential.; (ii) the second is described as slow, and consists of absorption and signaling of toxic ions, such as $\mathrm{Na}^{+}$[77]. The main ions involved in salt stress signaling are cations, such as $\mathrm{Na}^{+}, \mathrm{Ca}_{2}{ }^{+}, \mathrm{Mg}_{2}{ }^{+}$, and $\mathrm{K}^{+}$, and anions, such as $\mathrm{Cl}^{-}, \mathrm{SO}_{4}{ }^{-}, \mathrm{HCO}_{3}{ }^{-}, \mathrm{CO}_{3}{ }^{2-}$ and $\mathrm{NO}_{3}{ }^{-}$, as it is through the interaction of these ions that cell homeostasis occurs. Plants under extreme salinization conditions limit the entry of $\mathrm{Na}^{+}$or accumulate this ion in their older tissues, providing the formation of a "stock" environment, which will later be eliminated. Plants that, throughout evolution, have shown characteristics and mechanisms adaptable to the saline environment are described as halophyte plants. Several comprehensive reviews have been published on various aspects of halophyte physiology [78,79]. Halophyte plants have developed three main strategies to adapt to saline soils stress: uptake of high-concentration ions and store in vacuoles, removal of absorbed salts by special cells, and restriction of salt uptake by stem cells [80]. Salinity-sensitive plants (glycophytes) can accumulate minimal amounts of $\mathrm{Na}^{+}$ and $\mathrm{Cl}^{-}$. Glycophytes are more sensitive to the accumulation of these ions in their tissues due to improper salt compartmentation, harming development and productivity [60]. The roots are usually the first organ to sense the salt signal after plants are exposed to saline conditions [81]. The root architecture modifications in response to salinity are mediated by the suppression of cell division, initiation, elongation, or growth redirection away from salt [82]. In addition, to adapt to stressful conditions, plants can acquire tolerance by modifying root developmental processes that require metabolic alterations. In this sense, Chun et al. (2019) [83] showed that in callus suspension, salt-adapted cell cultures from Arabidopsis roots accumulated higher levels of sugars, amino acids, and intermediary metabolites in the shikimate pathway, such as coniferin. Moreover, adapted cells acquired thicker cell walls with higher lignin contents, suggesting the importance of adjusting physical properties during adaptation to high-saline conditions. Another typical response to salt stress is an increase in the root-shoot ratio, associated with water stress, rather than a specific effect of salt [80]. A greater root proportion under salt stress can favor the retention of toxic ions in this organ, controlling their translocation to the aerial parts [84]. Furthermore, a high spatial distribution of roots under salt stress can favor water absorption due to plants' increased soil exploration [81]. These responses may constitute a typical plant resistance mechanism in saline conditions.

The increase in the concentration of soluble organic compounds in the cytoplasm of cultivated plants subjected to salt stress is a mechanism used by plants to balance the osmotic potential between the cytosol, vacuole, and external environment [85]. In addition, these compounds prevent damage to the enzymatic systems and stabilize the structures of the enzyme [86]. The osmotic adjustment can be performed by some compounds that plants often produce and/or accumulate in stress situations, including quaternary derived from amino acids such as proline, glycine, glycine betaine, $\beta$-alanine, and complex sugars such as raffinose [87]. For example, in kiwi plants (glycophyte species) subjected to $0.3 \%$ and $0.6 \%$ sodium chloride $(\mathrm{NaCl})$, an increase in proline levels was observed in all genotypes [88]. In salt stress conditions, there was also an increase in the proline content and growth rate in Zea mays [89]. The accumulation of proline in the cell wall can reduce the effects of external disturbances on plants and increase the salt tolerance in Glycine max L. [90]. Plazek et al. (2013) [91] describe that, in halophytes, this osmolyte can act directly on the osmotic pressure, while in glycophytes, proline can play two roles, playing both an osmotic function and acting in the stabilization of the tertiary structure of proteins. In addition to this osmoprotective function, these osmolytes help in the redox balance within the cell and maintain the provision of energy, carbon, and nitrogen in plants [92]. Analyses performed on C. arabica leaves under salt stress $(150 \mathrm{mM} \mathrm{NaCl})$ showed changes in cell wall polysaccharides and increased monolignol content, which confers a barrier for salt entrance [93]. 
The photosynthetic process is involved in productivity and nutrient flows in plants. Salinity affects the physiological activity of the leaf, particularly photosynthesis, which is the main cause of reduced plant productivity [94]. Exposure to salinity leads to stomatal closure, which reduces the photosynthesis ratio due to a decrease in stomatal conductance, which restricts the access of $\mathrm{CO}_{2}$ for the Calvin-Benson cycle [95]. In addition, the effects of salinity on photosynthesis may involve inhibition of electron transport and inactivation of the photosystem II (PSII) reaction centers [96], destroying the oxygen-evolving complex (OEC), and impairing the electron transfer capacity on the donor side of PSII [97]. The salinity led to a decrease in photosynthetic rate, leaf osmotic potential, electron transport rate, and $\mathrm{CO}_{2}$ concentrations in the chloroplasts of rice leaves [98]. PSII is damaged by salinity. This was observed in cultivars of wheat, in which the total chlorophyll contents and quantum yield of PSII significantly decreased due to salt stress (150 mM) [99]. Exposure to $300 \mathrm{mM} \mathrm{NaCl}$ caused a decrease in stomatal conductance from day three and a reduction in water potential, $\mathrm{CO}_{2}$ assimilation, and in the maximum quantum yield of photosystem II (Fv/Fm) from day nine in leaves of Portulaca oleracea L. [100]. In addition, a decrease in chlorophyll content is a commonly reported phenomenon under salt stress. Some studies propose that chlorophyll concentration can be used as a possible indicator of the cellular metabolic state [101]. In rice leaves, the reduction of the chlorophyll a and $b$ content of the leaves was observed after treatment with $\mathrm{NaCl}(200 \mathrm{mM} \mathrm{NaCl}, 14$ days), where the chlorophyll b content of the leaves (41\%) was affected more than the content of chlorophyll a $(33 \%)$ [102].

Salinity induces oxidative stress in plants at the subcellular level $[80,103]$. ROS are formed due to the reduction of oxygen by reducing molecules. Their concentration increases due to environmental stress, and the stomata close to reduce water losses. The $\mathrm{CO}_{2}$ in the leaves is reduced so that the reducing power of NADPH, or reduced ferredoxin, is conveyed to oxygen, which is, therefore, reduced in its radical forms, superoxide $\left(\mathrm{O}_{2} \bullet-\right)$, hydrogen peroxide $\left(\mathrm{H}_{2} \mathrm{O}_{2}\right)$, and hydroxyl radical (HO') [104]. This increase in ROS level in plant tissues results in oxidative damage of membrane lipids, proteins, and nucleic acids [105]. To scavenge high ROS levels, plants develop an efficient system of non-enzymatic and enzymatic antioxidants [106]. Non-enzymatic antioxidants include reduced ascorbate (ASC), glutathione (GSH), phenolics, flavonoids, and tocopherols [107]. Enzymatic antioxidants responsible for detoxifying ROS accumulation include superoxide dismutase (SOD; EC 1.15.1.1), peroxidase (POX; EC 1.11.1.7), catalase (CAT; EC 1.11.1.6), and the enzymes of the ascorbate (ASC)-glutathione (GSH) cycle: GSH reductase (GR), ASC peroxidase (APX; EC 1.11.1.11), monodehydroascorbate dehydrogenase (MDHAR; EC 1.6.5.4), and dehydroascorbate reductase (DHAR; EC 1.15.1.1) [105,108].

Up-regulation of antioxidants was observed in different cultivated plants like rice, wheat, maize, soybean, and tomato $[98,99,105,109,110]$. Salt-tolerant cultivars demonstrated that the increased resistance to salinity is associated with the alleviation of oxidative damage is often correlated with an efficient antioxidative system. In addition, many studies have demonstrated the role of enzymatic and non-enzymatic antioxidants in medicinal plants as Lonicera japonica L., Hyssopus officinalis L., Melissa officinalis L., and Curcuma longa L. [111-114]. This evidences the role of antioxidants in alleviating salt stress-induced oxidative damage.

Among the changes arising from the excess of these ions, one of great importance is the decrease in water absorption by the plant, which ion toxicity can cause a reduction in nutrient absorption. In this way, salt stress induces a potassium (K) deficiency with an increase in salinity. In salt, stress incurs the accumulation of $\mathrm{Na}^{+}$, which is accompanied by a sharp decrease in $\mathrm{K}^{+}$content $[105,110,115]$. This inverse relationship is due to the competition between $\mathrm{Na}^{+}$and $\mathrm{K}^{+}$uptake in the roots. For example, in wheat cultivars under salt stress $(150 \mathrm{mM})$, the growth and yield were reduced due to a decline in plant water status, limited uptake of macronutrients (, $\mathrm{P}$, and $\mathrm{K})$, and reduced $\mathrm{K}^{+} / \mathrm{Na}^{+}$ratio [99]. In addition, salinity can interfere with the acquisition and use of nitrogen $(\mathrm{N})$ by plants, influencing the different steps of $\mathrm{N}$ metabolism: absorption, assimilation, and synthesis 
of proteins. Li et al. (2019) [116] showed that salt stress significantly inhibited the $\mathrm{N}$ assimilation process in cucumber leaves. In this sense, the nutrient imbalance contributes to reducing growth rate under stressful salinity conditions.

\subsection{Molecular Approachs to Salt Stress}

The decoding of genome sequences of diverse major food crops provides useful genomic information related to structural, functional, and comparative genomics for novel trait discovery and genetic enhancement of cultivated crops [117]. For example, to increase crop production in saline soils, identifying quantitative trait loci (QTLs) associated with salt tolerance is an essential step for improving varieties of salt-tolerant plants [118]. In this way, different QTLs associated with salt tolerance have been identified in cultivated crops: soybean [119,120]; maize [121] and rice [122,123] (Supplementary Table S1). The QTLs were mainly identified for various agronomic traits, including physiological and agronomic traits involved in salinity tolerance, yield and yield contributing factors, and root architecture (Supplementary Table S1).

By integrating diverse omics approaches, it is possible to understand what changes occur in the gene expression, proteins, and metabolites, in response to salt stress. Studies from genomics, transcriptomics, proteomics, metabolomics, and epigenomics have been developed to understand the salt stress tolerance process and its possible use to increase salinity tolerance in plants. With the development of several advanced technologies, including CRISPR/Cas9, which can be used for target-site genome editing to gain salttolerant cultivars. Some recent examples were developed for rice [124,125] and tomato [126] Other examples of molecular approaches used to understand and to develop salt-tolerant plants are also reported in Supplementary Table S1.

Salinity tolerance can trigger and alter the expression of numerous genes, divided into different functional groups, responsible for minimizing the effects of excess salt [61]. These genes are involved with photosynthetic proteins, proteins linked to transport the vacuole, synthesis of osmolytes, membrane channels, and activation of protectors against ROS, and signaling/regulatory elements, including TFs. According to a study carried out by Roy et al. (2014) [127], overexpression of genes involved in ROS removal resulted in decreased cell damage, maintenance of photosynthetic energy, and an improvement in root growth under saline conditions. The same also occurs in the overexpression of $\mathrm{H}^{+}$and potassium antiport channels, which allow the greatest accumulation of biomass associated with greater tolerance to salinity [128].

Among TF, the major TFs are bZIP, DREB, MYC, MYB, NAC, and WRKY, which strongly correlate with salinity and are identified with great potential in promoting crop tolerance against salt stress. Wang et al. (2021) [99] showed that overexpression of ThNAC12 TF enhanced salt tolerance through modulation of ROS scavenging via direct regulation of ThPIP2;5 expression in Tamarix hispida. In transgenic rice, the SiMYB19 overexpression promotes abscisic acid (ABA) accumulation and upregulates the ABA synthesis gene OsNCED3 and the ABA signal transduction pathway-related genes OsPK1 and OsABF2 [129]. Under salt stress, the overexpression technology combined with the CRISPR-Cas9 system shows that GmNAC06 TF could cause the accumulation of proline and glycine betaine to alleviate or avoid the negative effects of ROS; similarly, it could control the $\mathrm{Na}^{+} / \mathrm{K}^{+}$ratios in hairy roots to maintain ionic homeostasis in G. max. In this way, GmNAC06 plays a role in response to salt stress and could be useful in generating salt-tolerant transgenic crops [130]. The development of these new methodologies will generate new avenues for harnessing and exploring these tools to improve agriculture traits.

\section{Heat Stress}

In the near future, global warming will provide a challenge for crops in maintaining their development, growth, reproduction, and yield [131]. To minimize the effects of heat stress, plants have evolved a series of mechanisms, including molecular responses and changes in their physiology and biochemistry, to try to defend against the damage 
caused by temperature elevation $[132,133]$. These changes have damaged agricultural production [134]. Plants are subject to heat stress when: (i) the air temperature is high, and plants receive energy through sensible heat transfer; (ii) solar radiation incident on the soil surface raises the temperature above the air temperature; and (iii) in leaves, substantial heating caused by solar radiation and inability to dissipate heat can result in leaves heating very quickly (up to $15^{\circ} \mathrm{C}$ above air temperature), so leaves with low transpiration rates are often subjected to high temperatures [135].

The exposition to thermal stress can cause enormous damage to the cell membrane and the protein conformation, leading to ROS production, triggering oxidative stress. In addition, heat stress decreased protein synthesis, transcription, and translation of heat shock proteins (HSPs), production of phytohormones and antioxidants, and changes in the organization of cell structures leading to alterations in hormonal homeostasis [136,137].

\subsection{Response Mechanisms to Heat Stress}

To bear heat stress, plants change their morphology by increasing the root system, reducing the stomatal number and conductance while the leaf curls, folds, and decreases its area, becoming thinned to avoid water loss by evapotranspiration [138,139]. Previously, Lima et al. (2013) [140] studied the cell wall structure of coffee plants subjected to heat stress $\left(37^{\circ} \mathrm{C}\right)$, which showed changes related to cell wall stiffening, as well as an increase in the structural size of the wall polysaccharides and in the lignin content. Regarding structure, the period of thermal stress led to a decrease in the content of starch granules, changes in the organization of internal membranes, and a decrease in the general size of the mesophyll cells, especially in the palisade parenchyma [140].

Abiotic factors such as high temperatures combined with water shortage affect the growth and development of many plants, decreasing crop productivity. Heat stress causes numerous disturbances to plants, altering the stability of membranes and proteins, disorganizing the metabolism of nucleic acids and proteins, degenerating membrane structure, inhibiting photosynthesis, among other adverse effects (Figure 3).

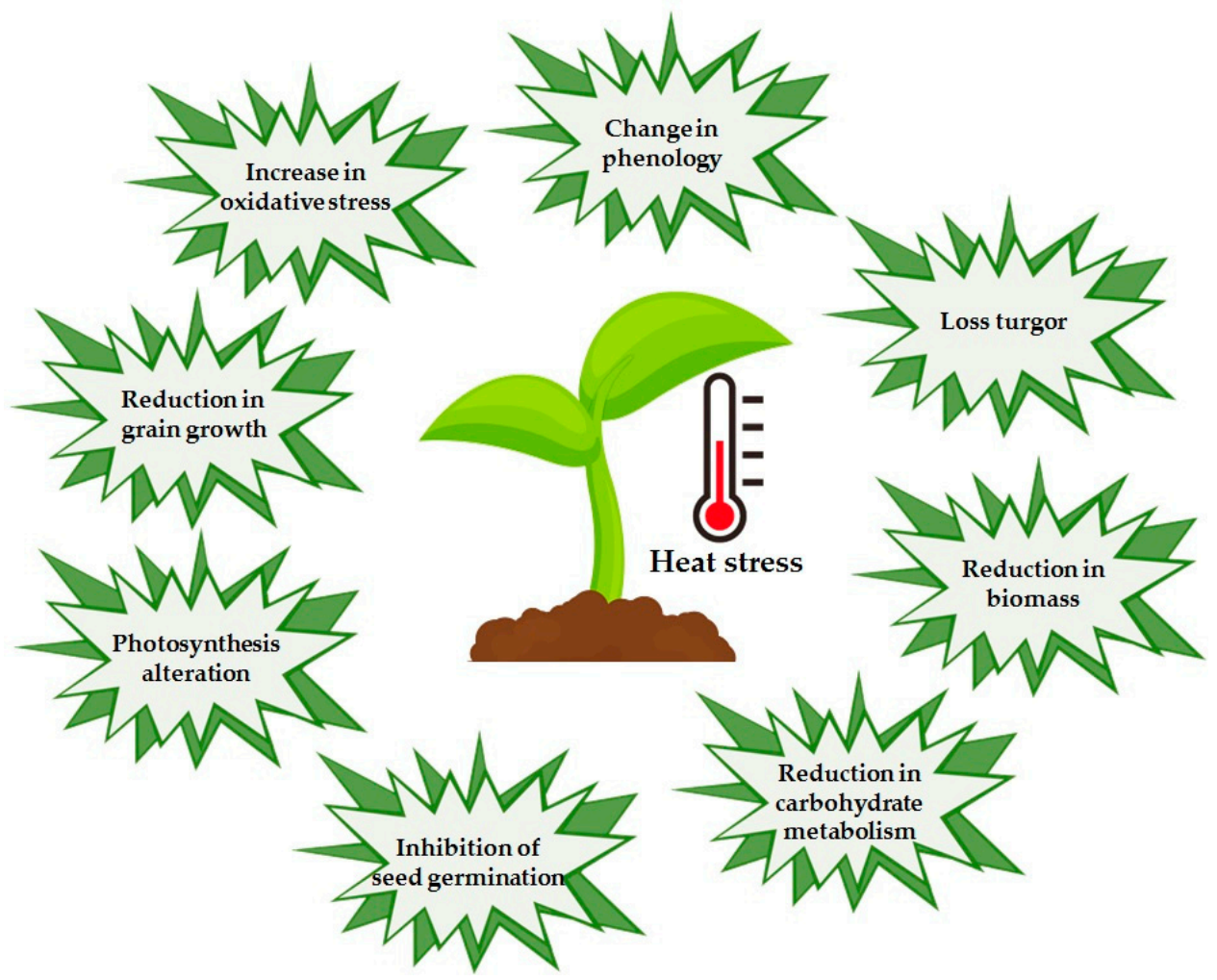

Figure 3. Some of the effects triggered by heat stress on plants. 
Heat stress causes physiological adjustments in plants. The photosynthetic apparatus is usually damaged, decreasing transpiration due to stomatal closure and $\mathrm{CO}_{2}$ content, inhibiting photosynthetic enzymes and ATP synthases rates, reducing leaf expansion, and accelerating senescence; as a consequence, plant development is hampered [141-143]. To mitigate the effects of heat stress, the metabolism of carbon assimilation is altered, remobilizing plants' starch reserve in chloroplasts by releasing energy, sugars, and derived metabolites to survive stress periods and prevent further damage [144,145].

The ribulose 1,5 bisphosphate carboxylase/oxygenase (Rubisco) enzyme, central to carbon fixation, usually works efficiently between temperatures of 20 and $30{ }^{\circ} \mathrm{C}$. Above these conditions, photosynthetic rates tend to be reduced [146]. Throughout evolution, plants have developed different metabolic strategies that have allowed them to react to adverse conditions. The C4 and CAM photosynthetic mechanisms present structures for concentrating $\mathrm{CO}_{2}$ that provide the Rubisco with greater photosynthetic efficiency, even under extreme high-temperature conditions, except in C3 plants [146]. However, most crops have a C3 metabolism, comprising species which usually fix less carbon under high temperatures, as they do not have optimized mechanisms for $\mathrm{CO}_{2}$ concentration [147].

Heat stress interferes with redox homeostasis, leading to ROS production, harming the elimination mechanisms of these toxic forms of $\mathrm{O}_{2}$ in different cell compartments, causing oxidative stress. The increase in ROS produces molecule oxidation, membrane decomposition, enzyme inactivation, and changes in gene expression [133]. ROS-scavenging enzymes such as SOD, CAT, APX, monodehydroascorbate reductase (MDHAR), DHAR, and glutathione reductase (GR) play a role in detoxifying the excess of ROS produced by cells under stress conditions [148], as well as non-enzymatic mechanisms (ascorbate-ASA, glutathione-GSH, $\alpha$-tocopherol, and flavonols). Oxidative stress also leads to epigenetics, including histone modifications regulating the gene expression [149,150]. Manipulation of photosynthesis through rubisco activase and enzymes functioning in the detoxification of reactive oxygen species is a suitable approach for generating heat-tolerant crop plants [151].

Plants can perceive changes in temperature through sensors in different cellular compartments. Chloroplasts that house the photosynthetic apparatus, the most damaged by heat, are considered sensors of heat stress because they change the dynamics in response to ROS/redox changes at the cellular level [152]. The signals generated by these different sensors rapidly trigger a specific signal transduction network that involves calcium fluxes, calmodulin, CDPKs, mitogen-activated protein kinases (MAPKs), phosphatases, and transcriptional regulators [149].

One of the best-known means of responding to potential damage caused by high temperatures is through the synthesis of HSPs, a group of protective proteins including Hsp100, Hsp90, Hsp70, Hsp60, small Hsps, and some MAPKs [149,153,154]. Heat stress-responsive genes are regulated by a series of TFs, including heat stress TFs (HSFs), NAC, MYB, WRKY, $\mathrm{RAV}, \mathrm{bZIP}, \mathrm{AP} 2 / \mathrm{ERF}$, and ZAT that regulate the expression of stress-responsive genes. The transcription is activated by binding the cis-elements (ARE, CORE, W-box, GCC box, as-1 like) in the promoters of such stress-inducible genes [133]. Genes responsive to heat stress such as NADPH oxidases (Rboh), dehydration-responsive element-binding protein 2A (DREB2A), heat shock (HsfA2, HsfA7a, HsfBs), multiprotein bridging factor 1C (MBF1C), and MAPK are regulated by such HSFs. Additionally, TFs, epigenetic regulators, and small RNAs also regulate heat stress-responsive genes [149].

Plants under heat stress also increase the biosynthesis of several hormones to regulate their response to stress. Temperature elevation stimulates the biosynthetic pathways of hormones such as auxins, salicilic acid (SA), ABA, brassinosteroids (BRs), cytokinin $(\mathrm{CK})$, jasmonate (JA), and ethylene (ET), resulting in higher accumulation in plant cells as a manner to tolerate heat stress [137]. The overexpression TaNAC2L transcription factor activated the expression of heat-related genes in the transgenic Arabidopsis plants, suggesting that TaNAC2L may improve heat tolerance by regulating the expression of stressresponsive genes [155]. However, the overexpression of NAC transcription factor (S1JA2) reduced the accumulation of SA in transgenic tobacco, resulting in increased susceptibility 
to heat stress [156]. In this way, the transcription factors binding genes from hormone biosynthesis pathway should be analyzed whether they work as positive or negative regulators to genetic engineering plants to improve heat stress tolerance.

\subsection{Approaches to Generate Heat-Tolerant Plants}

Conventional breeding to develop heat stress tolerance genotypes is very difficult, since this trait is usually complex, being controlled by several genes present at multiple QTL. Moreover, germoplasm evaluation is time-consuming and costly [157]. Although it is challenging, QTLs associated with heat tolerance have been identified in recent years, for example, in the wheat [128,158-163], barley [164], chickpea [165], cotton [165,166], tomato [167,168], and rice [169], among other crops (Supplementary Table S1).

Whenever these characteristics are found in commercial or wild relatives, conventional breeding, mainly assisted by molecular tools, can be used to improve heat tolerance in commercial genotypes [170]. However, it is necessary to keep in mind that an undesirable portion of the genome, mainly from wild relatives, could be transferred to the target genotype by crosses [168,171].

Metabolome has been a valuable tool for understanding how plants behave under heat stress. In response to high temperatures, plants change their metabolism to accumulate assimilates, mainly sugars, amino acids, and carbohydrates [145,172-178] (Supplementary Table S1).

Transgenic approaches have also been of great interest for generating abiotic stresstolerant plants in recent years. Heat stress factors and DREB2A genes have been identified to engineer transgenic plants tolerant to heat [148,179]. Genes coding to molecular chaperons (HSP, EF-Tu), osmolytes (glycine betaine), sugars (trehalose-6-phosphate synthase (TPS) and trehalose-6-phosphate phosphatase (TPP), antioxidant enzymes (peroxisome-located ascorbate peroxidase (APX), glutathione peroxidase gene, $\mathrm{Cu} / \mathrm{Zn}$ superoxide dismutase) and transcriptions factors (AP2/EREBP, WRKY, NAC, MYB and basic leucine zipper (bZIP)) have been proved to increase tolerance to heat stress by transgenic approaches [180]. In addition to such genes, plant nucleoside diphosphate kinase 2 (NDPK2), CBF3, antioxidative enzyme 2-cysteine peroxiredoxin (2-Cys Prx), have been assayed in Solanum tuberosum to increase heat tolerance [181]. The overexpression of heat shock protein 70 (AsHSP70) and 101 (AtHSP101), pyrophosphate-energized vacuolar membrane proton pump 1 (AVP1), and Arabidopsis SUMO E3 ligase (OsSIZ1) genes in cotton proved to increase heat tolerance of this plant [182].

However, the overexpression of HSFs could affect developmental and stress responses in an undesirable way [183]. For the overexpression of such genes, tissue-specific and stressinducible promoters should be preferable to decrease the impact on plant growth $[181,184]$. Manipulation of photosynthesis through Rubisco activase and enzymes functioning in ROS detoxification are also candidate genes to generate heat-tolerant crop plants.

Modification of the cell wall structure in plants, leading, for example, to increased levels of expansin, can help to increase tolerance to high temperatures through the loosening and relaxation of the cell wall. In this sense, the overexpression of the expansin gene PpEXP1 in the grass Poa pratensis improved heat tolerance $\left(35^{\circ} \mathrm{C}\right)$, with less structural damage to the cells [185]. In the thale cress Arabidopsis thaliana, it was shown that the production of enzymes involved in the biosynthesis of oligosaccharides of the raffinose family, as well as the accumulation of these carbohydrates, play crucial roles in tolerance during heat stress, possibly acting as an osmoprotectant [186].

Although transgenic approaches are suitable for engineering heat-stress-tolerant plants, public concern and regulatory issues regarding the release of such GMO cultivars present difficulties to the process [182]. On the other hand, the genome edition (GEd) approach has become the most used system to modify plants by disrupting genes (knockout) or inserting fragments (knock-in) or regulatory elements to genes' promoters to modulate gene expression $[187,188]$. The most recent technique used to edit plant genomes is clustered regularly interspaced short palindromic repeats (CRISPR) associated with protein9 
nuclease (Cas9). To obtain heat-tolerant plants, CRISPR-Cas can be used to either active or repress genes in a very specific way. For example, positive gene regulators associated with HSPs and stress-related TFs can be activated, or negative regulators can be silenced by the CRISPR-Cas system [189]. The advantage of GEd is that in cases of gene disruption or silencing, the plants could be considered transgene-free in some countries, facilitating the development of new varieties.

Similarly, plant microRNAs (miRNAs) function as positive or negative regulators, which have been studied as targets for genetic engineering tolerance to heat stress $[190,191]$ by transgenesis or genome editing approaches [192]. For instance, the overexpression of miR156 in Arabidopsis increased tolerance to heat stress [149]. Several miRNAs were differentially regulated in two contrasting rice genotypes under different heat stress treatments, suggesting that the tolerant cultivar was more efficient in its use of molecular and physiological machinery at the reproductive stage than the susceptible one after heat stress, making it a candidate for genetic engineering [155] Supplementary Table S1.

\section{Conclusions and Future Outlook}

The scientific community emphasizes the importance of increasing yield crop farming due to food demand and population increase. However, there is a certain neglect regarding how to correctly use biotechnological tools to minimize the adverse effects caused by abiotic stresses in morphological, physiological, biochemical, and molecular processes. Given such a problem with which our agriculture has been confronted, the big questions are what and how to correctly apply the information generated by these techniques to really mitigate these adversities?

Bearing this in mind, we aggregated the main mechanisms involved in the stresses of greatest impact in recent decades for agriculture. With this approach, we want to improve and increase the understanding of these processes. Advances in molecular genomic tools including MAS, QTL mapping, high-throughput DNA sequencing (including long read technologies), RNA sequencing (RNA-seq), chromatin immunoprecipitation sequencing (ChIP-seq), genome-wide association study (GWA study), genomic selection (GS), proteomics and metabolomics approaches, and CRISPR technologies are of fundamental relevance to understanding the complex mechanisms of abiotic stresses in plants and developing new resilient cultivars $[136,145,157,193,194]$. Although a myriad of new approaches have emerged in the last 20 years, it is probable that the integration of such analyses, rather than new techniques, will deliver the best approaches for plant breeding for abiotic stresses throughout this decade.

Supplementary Materials: The following are available online at https:/ / www.mdpi.com/article/ 10.3390/stresses2010009/s1, Table S1: Molecular approaches to develop resilient plants to abiotic stresses (drought, heat, and salinity).

Author Contributions: Wrote, reviewed, and edited the paper, T.B.d.S.; Wrote and reviewed the paper, A.F.R.; Wrote and reviewed the paper, S.G.H.d.S.; Wrote and reviewed the paper, I.G.F.B.; revised the paper and gave positive suggestions on the article, D.S.D. All authors have read and agreed to the published version of the manuscript.

Funding: D.S.D. has his research on coffee abiotic stresses funded by FAPESP (\#2018/08042-8) and CNPq (312823/2019-3). I.G.F.B. was supported financially by the Brazilian research funding agency CAPES (Coordenação de Aperfeiçoamento Pessoal de Nível Superior) (grant: 88887.373993/2019-00). A.F.R. CNPq-Universal funding (404745/2018-0).

Institutional Review Board Statement: Not applicable.

Informed Consent Statement: Not applicable.

Data Availability Statement: Not applicable.

Conflicts of Interest: The authors declare no conflict of interest. 


\section{Abbreviations}

\begin{tabular}{|c|c|}
\hline WUE & water use efficiency \\
\hline $\mathrm{ABA}$ & abscisic acid \\
\hline ETC & electron transport chain \\
\hline ROS & reactive oxygen species \\
\hline ATP & adenosine triphosphate \\
\hline NADH & nicotinamide adenine dinucleotide \\
\hline TCA & tricarboxylic acid cycle \\
\hline $\mathrm{AOX}$ & alternative oxidase \\
\hline GABA & $\gamma$-aminobutyric acid \\
\hline $\mathrm{NO}$ & nitric oxide \\
\hline HR & hypersensitive response \\
\hline PCD & programmed cell death \\
\hline MAS & marker-assisted selection \\
\hline GWAS & genome-wide selection \\
\hline QTL & quantitative trait loci \\
\hline PSII & photosystem II \\
\hline RWC & relative water content \\
\hline PGRs & plant growth regulator \\
\hline OEC & oxygen-evolving complex \\
\hline ASC & ascorbate \\
\hline GSH & glutathione \\
\hline SOD & superoxide dismutase \\
\hline POX & peroxidase \\
\hline CAT & catalase \\
\hline GSH & glutathione \\
\hline APX & ascorbate peroxidase \\
\hline MDHAR & monodehydroascorbate dehydrogenase \\
\hline DHAR & dehydroascorbate reductase \\
\hline K & potassium \\
\hline $\mathrm{N}$ & nitrogen \\
\hline HSPs & heat shock proteins \\
\hline GR & glutathione reductase \\
\hline SA & salicilic acid \\
\hline BRs & brassinosteroids \\
\hline CK & cytokinin \\
\hline JA & jasmonate \\
\hline ET & ethylene \\
\hline CuZn-SOD & copper-zinc superoxide dismutase \\
\hline Ged & genome edition \\
\hline RNA-seq & RNA sequencing \\
\hline ChIP-seq & chromatin immunoprecipitation sequencing \\
\hline GWA & genome-wide association \\
\hline GS & genomic selection \\
\hline
\end{tabular}

\section{References}

1. Zhang, H.; Zhu, J.; Gong, Z.; Zhu, J. Abiotic stress responses in plants. Nat. Rev. Genet. 2021, 23, 104-119. [CrossRef] [PubMed]

2. Uddling, J.; Broberg, M.C.; Feng, Z.; Pleijel, H. Crop Quality under Rising Atmospheric $\mathrm{CO}_{2}$. Curr. Opin. Plant Biol. 2018, 45, 262-267. [CrossRef] [PubMed]

3. Poorter, H.; Knopf, O.; Wright, I.J.; Temme, A.A.; Hogewoning, S.W.; Graf, A.; Cernusak, L.A.; Pons, T.L. A meta-analysis of responses of $\mathrm{C} 3$ plants to atmospheric $\mathrm{CO}_{2}$ : Dose-response curves for 85 traits ranging from the molecular to the whole-plant level. New Phytol. 2021, 233, 1560-1596. [CrossRef] [PubMed]

4. $\quad$ Menezes-Silva, P.E.; Sanglard, L.M.; Ávila, R.T.; Morais, L.E.; Martins, S.C.; Nobres, P.; Patreze, C.M.; Ferreira, M.A.; Araújo, W.L.; Fernie, A.R. Photosynthetic and metabolic acclimation to repeated drought events play key roles in drought tolerance in coffee. J. Exp. Bot. 2017, 68, 4309-4322. [CrossRef] [PubMed] 
5. Bryant, C.; Fuenzalida, T.I.; Brothers, N.; Mencuccini, M.; Sack, L.; Binks, O.; Ball, M.C. Shifting access to pools of shoot water sustains gas exchange and increases stem hydraulic safety during seasonal atmospheric drought. Plant Cell Environ. 2021, 44, 2898-2911. [CrossRef]

6. Tenhaken, R. Cell wall remodeling under abiotic stress. Front. Plant Sci. 2014, 5, 771. [CrossRef]

7. Demidchik, V. Mechanisms of oxidative stress in plants: From classical chemistry to cell biology. Environ. Exp. Bot. 2015, 109, 212-228. [CrossRef]

8. Makarevitch, I.; Waters, A.J.; West, P.T.; Stitzer, M.; Hirsch, C.N.; Ross-Ibarra, J.; Springer, N.M. Transposable elements contribute to activation of maize genes in response to abiotic stress. PLoS Genet. 2015, 11, e1004915.

9. Hou, Q.; Ufer, G.; Bartels, D. Lipid signalling in plant responses to abiotic stress. Plant Cell Environ. 2016, 39, 1029-1048. [CrossRef]

10. Nakabayashi, R.; Saito, K. Integrated metabolomics for abiotic stress responses in plants. Curr. Opin. Plant Biol. 2015, 24, 10-16. [CrossRef]

11. Choudhury, F.K.; Rivero, R.M.; Blumwald, E.; Mittler, R. Reactive Oxygen species, abiotic stress and stress combination. Plant J. 2017, 90, 856-867. [CrossRef] [PubMed]

12. Bhargava, S.; Sawant, K. Drought stress adaptation: Metabolic adjustment and regulation of gene expression. Plant Breed. 2013, 132, 21-32. [CrossRef]

13. Food and Agriculture Organization of the United Nations. Overcoming water challenges in agriculture. In The State of Food and Agriculture 2020; FAO: Rome, Italy, 2020.

14. Gimenez, C.; Gallardo, M.; Thompson, R.B. Plant water relations. In Encyclopedia of Soils in the Environment; Hillel, D., Ed.; Elsevier: Oxford, UK, 2005; pp. 231-238.

15. Kabbadj, A.; Makoudi, B.; Mouradi, M.; Pauly, N.; Frendo, P.; Ghoulam, C. Physiological and biochemical responses involved in water deficit tolerance of nitrogen-fixing Vicia faba. PLoS ONE 2017, 12, e0190284. [CrossRef] [PubMed]

16. Salehi-Lisar, S.Y.; Motafakkerazad, R.; Hossain, M.M.; Rahman, I.M.M. Water stress in plants: Causes, effects and responses. In Water Stress; Rahman, M., Hasegawa, H., Eds.; InTech: Rijeka, Croatia, 2012; pp. 1-14.

17. Salehi-Lisar, S.Y.; Bakhshayeshan-Agdam, H. Drought stress in plants: Causes, consequences, and tolerance. In Drought Stress Tolerance in Plants; Springer: Berlin, Germany, 2016; Volume 1, pp. 1-16.

18. Bray, E. Plant response to water deficit stress. In Encyclopedia of Life Sciences (ELS); John Wiley \& Sons: Hoboken, NJ, USA, 2007; Volume 1, pp. 1-7.

19. O'Connell, E. Towards adaptation of water resource Systems to climatic and socio-economic Chang. Water Resour. Manag. 2017, 31, 2965-2984. [CrossRef]

20. Hatfield, J.L.; Dold, C. Water-Use Efficiency: Advances and Challenges in a Changing Climate. Front. Plant Sci. 2019, 10, 103. [CrossRef] [PubMed]

21. Schulz, P.; Piepenburg, K.; Lintermann, R.; Herde, M.; Schottler, M.A.; Schmidt, L.K.; Ruf, S.; Kudla, J.; Romeis, T.; Bock, R. Improving plant drought tolerance and growth under water limitation through combinatorial engineering of signaling networks. Plant Biotechnol. J. 2021, 19, 74-86. [CrossRef]

22. Nuccio, M.L.; Wu, J.; Mowers, R.; Zhou, H.-P.; Meghji, M.; Primavesi, L.F.; Paul, M.J.; Chen, X.; Gao, Y.; Haque, E.; et al. Expression of trehalose-6-phosphate phosphatase in maize ears improves yield in well-watered and drought conditions. Nat. Biotechnol. 2015, 33, 862-869. [CrossRef]

23. Damerum, A.; Smith, H.K.; Clarkson, G.; Truco, M.J.; Michelmore, R.W.; Taylor, G. The genetic basis of water-use efficiency and yield in lettuce. BMC Plant Biol. 2021, 21, 237. [CrossRef]

24. Jia, X.; Mao, K.; Wang, P.; Wang, Y.; Jia, X.; Huo, L.; Sun, X.; Che, R.; Gong, X.; Ma, F. Overexpression of MdATG8i improves water use efficiency in transgenic apple by modulating photosynthesis, osmotic balance, and autophagic activity under moderate water deficit. Hortic. Res. 2021, 8, 81. [CrossRef]

25. Baidyussen, A.; Jatayev, S.; Khassanova, G.; Amantayev, B.; Sereda, G.; Sereda, S.; Gupta, N.K.; Gupta, S.; Schramm, C.; Anderson, P.; et al. Expression of Specific Alleles of Zinc-Finger Transcription Factors, HvSAP8 and HvSAP16, and Corresponding SNP Markers, Are Associated with Drought Tolerance in Barley Populations. Int. J. Mol. Sci. 2021, 22, 12156. [CrossRef]

26. Cai, K.; Chen, X.; Han, Z.; Wu, X.; Zhang, S.; Li, Q.; Nazir, M.M.; Zhang, G.; Zeng, F. Screening of Worldwide Barley Collection for Drought Tolerance: The Assessment of Various Physiological Measures as the Selection Criteria. Front. Plant Sci. 2020, $29,1159$. [CrossRef]

27. Faillace, G.R.; Caruso, P.B.; Timmers, L.F.S.M.; Favero, D.; Guzman, F.L.; Rechenmacher, C.; de Oliveira-Busatto, L.A.; de Souza, O.N.; Bredemeier, C.; Bodanese-Zanettini, M.H. Molecular Characterisation of Soybean Osmotins and Their Involvement in Drought Stress Response. Front. Genet. 2021, 25, 632685. [CrossRef] [PubMed]

28. Kamphorst, S.H.; Gonçalves, G.M.B.; Amaral Júnior, A.T.D.; Lima, V.J.D.; Schmitt, K.F.M.; Leite, J.T.; Azeredo, V.C.; Gomes, L.P.; Silva, J.G.d.S.; Carvalho, C.M.; et al. Supporting Physiological Trait for Indirect Selection for Grain Yield in Drought-Stressed Popcorn. Plants 2021, 10, 1510. [CrossRef] [PubMed]

29. Santos, T.D.O.; Amaral Junior, A.T.D.; Bispo, R.B.; Lima, V.J.; Kamphorst, S.H.; Leite, J.T.; Júnior, D.R.d.S.; Santos, P.H.A.D.; de Oliveira, U.A.; Schmitt, K.F.M.; et al. Phenotyping Latin American Open-Pollinated Varieties of Popcorn for Environments with Low Water Availability. Plants 2021, 10, 1211. [CrossRef] [PubMed]

30. Barik, S.R.; Pandit, E.; Pradhan, S.K.; Mohanty, S.P.; Mohapatra, T. Genetic mapping of morpho-physiological traits involved during reproductive stage drought tolerance in rice. PLoS ONE. 2019, 14, e0214979. [CrossRef] 
31. Ghazy, M.I.; Salem, K.F.M.; Sallam, A. Utilization of genetic diversity and marker-trait to improve drought tolerance in rice (Oryza sativa L.). Mol. Biol. Rep. 2021, 48, 157-170. [CrossRef]

32. Pour-Aboughadareh, A.; Mohammadi, R.; Etminan, A.; Shooshtari, L.; Maleki-Tabrizi, N.; Poczai, P. Effects of Drought Stress on Some Agronomic and Morpho-Physiological Traits in Durum Wheat Genotypes. Sustainability 2020, 12, 5610. [CrossRef]

33. Li, P.; Ma, B.; Palta, J.A.; Ding, T.; Cheng, Z.; Lv, G.; Xiong, Y. Wheat breeding highlights drought tolerance while ignores the advantages of drought avoidance: A meta-analysis. Eur. J. Agron. 2021, 122, 126196. [CrossRef]

34. Kaur, H.; Kohli, S.K.; Khanna, K.; Bhardwaj, R. Scrutinizing the impact of water deficit in plants: Transcriptional regulation, signaling, photosynthetic efficacy, and management. Physiol. Plant 2021, 172, 935-962. [CrossRef]

35. Chevilly, S.; Dolz-Edo, L.; López-Nicolás, J.M.; Morcillo, L.; Vilagrosa, A.; Yenush, L.; Mulet, J.M. Physiological and Molecular Characterization of the Differential Response of Broccoli (Brassica oleracea var. Italica) Cultivars Reveals Limiting Factors for Broccoli Tolerance to Drought Stress. J. Agric. Food Chem. 2021, 69, 10394-10404. [CrossRef]

36. Mehari, T.G.; Xu, Y.; Umer, M.J.; Shiraku, M.L.; Hou, Y.; Wang, Y.; Yu, S.; Zhang, X.; Wang, K.; Cai, X.; et al. Multi-Omics-Based Identification and Functional Characterization of Gh_A06G1257 Proves Its Potential Role in Drought Stress Tolerance in Gossypium hirsutum. Front. Plant Sci. 2021, 21, 746771. [CrossRef] [PubMed]

37. Kapoor, D.; Bhardwaj, S.; Landi, M.; Sharma, A.; Ramakrishnan, M.; Sharma, A. The impact of drought in plant metabolism: How to exploit tolerance mechanisms to increase crop production. Appl. Sci. 2020, 10, 5692. [CrossRef]

38. Larcher, W. Climatic constraints drive the evolution of low temperature resistance in woody plants. J. Agric. Meteorol. 2005, 61, 189-202. [CrossRef]

39. Zingaretti, S.M.; Rodrigues, F.A.; Graca, J.P.; Pereira, L.M.; Lourenco, M.V. Sugarcane responses at water deficit conditions. In Water Stress, 1st ed.; Rahman, I.M.M., Ed.; IntechOpen: Shanghai, China, 2012; pp. 255-276.

40. Fang, Y.; Xiong, L. General mechanisms of drought response and their application in drought resistance improvement in plants. Cell. Mol. Life Sci. 2015, 72, 673-689. [CrossRef] [PubMed]

41. Cameron, K.D.; Teece, M.A.; Smart, L.B. Increased accumulation of cuticular wax and expression of lipid transfer protein in response to periodic drying events in leaves of tree tobacco. Plant Physiol. 2006, 140, 176-183. [CrossRef]

42. Perlikowski, D.; Kosmala, A. Mechanisms of drought resistance in introgression forms of Lolium multiflorum/Festuca arundinacea. Biol. Plant. 2020, 64, 497-503. [CrossRef]

43. Luo, L.J. Breeding for water-saving and drought-resistance rice (WDR) in China. J. Exp. Bot. 2010, 61, 3509-3517. [CrossRef]

44. Wittenmayer, L.; Merbach, W. Plant responses to drought and phosphorus deficiency: Contribution of phytohormones in root-related processes. J. Plant Nutr. Soil Sci. 2010, 168, 531-540. [CrossRef]

45. Takahashi, F.; Kuromori, T.; Urano, K.; Yamaguchi-Shinozaki, K.; Shinozaki, K. Drought Stress Responses and Resistance in Plants: From Cellular Responses to Long-Distance Intercellular Communication. Front. Plant Sci. 2020, 11, 556972. [CrossRef]

46. Yang, X.; Lu, M.; Wang, Y.; Wang, Y.; Liu, Z.; Chen, S. Response mechanism of plants to drought stress. Horticulturae 2021, 7, 50. [CrossRef]

47. Chan, Z. Expression profiling of ABA pathway transcripts indicates crosstalk between abiotic and biotic stress responses in Arabidopsis. Genomics 2012, 100, 110-115. [CrossRef] [PubMed]

48. Zhu, M.; He, Y.; Zhu, M.; Ahmad, A.; Xu, S.; He, Z.; Jiang, S.; Huang, J.; Li, Z.; Liu, S.; et al. Ipa1 improves rice drought tolerance at seedling stage mainly through activating abscisic acid pathway. Plant Cell Rep. 2022, 41, 221-232. [CrossRef]

49. Razi, K.; Muneer, S. Drought stress-induced physiological mechanisms, signaling pathways and molecular response of chloroplasts in common vegetable crops. Crit. Rev. Biotechnol. 2021, 41, 669-691. [CrossRef]

50. Pinheiro, C.; Chaves, M.M. Photosynthesis and drought: Can we make metabolic connections from available data? J. Exp. Bot. 2011, 62, 869-882. [CrossRef] [PubMed]

51. Galmés, J.; Medrano, H.; Flexas, J. Photosynthetic limitations in response to water stress and recovery in Mediterranean plants with different growth forms. New Phytol. 2007, 175, 81-93. [CrossRef] [PubMed]

52. Flexas, J.; Galmes, J.; Ribas-Carbo, M.; Medrano, H. The effects of water stress on plant respiration. In Plant Respiration: From Cell to Ecosystem; Lambers, H., Ribas-Carbo, M., Eds.; Springer: Berlin, Germany, 2005; pp. 85-94.

53. Hasanuzzaman, M.; Bhuyan, M.H.M.B.; Zulfiqar, F.; Raza, A.; Mohsin, S.M.; Mahmud, J.A.; Fujita, M.; Fotopoulos, V. Reactive oxygen species and antioxidant defense in plants under abiotic stress: Revisiting the crucial role of a universal defense regulator Antioxidants 2020, 9, 681. [CrossRef] [PubMed]

54. Vanlerberghe, G.C.; Martyn, G.D.; Dahal, K. Alternative oxidase: A respiratory electron transport chain pathway essential for maintaining photosynthetic performance during drought stress. Physiol. Plant 2016, 157, 322-337. [CrossRef]

55. Fait, A.; Fromm, H.; Walter, D.; Galili, G.; Fernie, A.R. Highway or byway: The metabolic role of the GABA shunt in plants. Trends Plant Sci. 2008, 13, 14-19. [CrossRef]

56. Khan, N.; Ali, S.; Shahid, M.A.; Mustafa, A.; Sayyed, R.Z.; Curá, J.A. Insights into the interactions among roots, rhizosphere, and rhizobacteria for improving plant growth and tolerance to abiotic stresses: A review. Cells 2021, 10, 1551. [CrossRef]

57. Xu, B.; Long, Y.; Feng, X.; Zhu, X.; Sai, N.; Chirkova, L.; Betts, A.; Herrmann, J.; Edwards, E.J.; Okamoto, M.; et al. GABA signalling modulates stomatal opening to enhance plant water use efficiency and drought resilience. Nat. Commun. 2021, $29,1952$. [CrossRef] 
58. El Sabagh, A.; Hossain, A.; Barutcular, C.; Gormus, O.; Ahmad, Z.; Hussain, S.; Islam, M.; Alharby, H.; Bamagoos, A.; Kumar, N.; et al. Effects of drought stress on the quality of major oilseed crops: Implications and possible mitigation strategies-A review. Appl. Ecol. Environ. Res. 2019, 17, 4019-4043. [CrossRef]

59. Ghaffari, H.; Tadayon, M.R.; Nadeem, M.; Cheema, M.; Razmjoo, J. Proline-mediated changes in antioxidant enzymatic activities and the physiology of sugar beet under drought stress. Acta Physiol. Plant 2019, 41, 23. [CrossRef]

60. Huan, L.; Jin-Qiang, W.; Qing, L. Photosynthesis product allocation and yield in sweet potato with spraying exogenous hormones under drought stress. J. Plant Physiol. 2020, 253, 153265. [CrossRef] [PubMed]

61. Hassan, N.; Ebeed, H.; Aljaarany, A. Exogenous application of spermine and putrescine mitigate adversities of drought stress in wheat by protecting membranes and chloroplast ultra-structure. Physiol. Mol. Biol Plants. 2020, 26, 233-245. [CrossRef]

62. Deshpande, S.; Manoharan, R.; Mitra, S. Exogenous $\beta$-cyclocitral treatment primes tomato plants against drought by inducing tolerance traits, independent of abscisic acid. Plant Biol. 2021, 23, 170-180. [CrossRef]

63. Xie, H.; Bai, G.; Lu, P.; Li, H.; Fei, M.; Xiao, B.G.; Chen, X.J.; Tong, Z.J.; Wang, Z.Y.; Yang, D.H. Exogenous citric acid enhances drought tolerance in tobacco (Nicotiana tabacum). Plant Biol. 2021, 24, 333-343. [CrossRef]

64. Hu, H.; Xiong, L. Genetic engineering and breeding of drought-resistant crops. Annu. Rev. Plant Biol. 2014, 65, 715-741. [CrossRef]

65. Cattivelli, L.; Rizza, F.; Badeck, F.-W.; Mazzucotelli, E.; Mastrangelo, A.M.; Francia, E.; Marè, C.; Tondelli, A.; Stanca, A.M. Drought tolerance improvement in crop plants: An integrated view from breeding to genomics. Field Crops Res. 2008, 105, 1-14. [CrossRef]

66. Rosero, A.; Granda, L.; Berdugo-Cely, J.A.; Šamajová, O.; Šamaj, J.; Cerkal, R. A dual strategy of breeding for drought tolerance and introducing drought-tolerant, underutilized crops into production systems to enhance their resilience to water deficiency. Plants 2020, 9, 1263. [CrossRef]

67. Ashraf, M. Inducing drought tolerance in plants: Some recent advances. Biotechnol. Adv. 2010, 28, 169-183. [CrossRef]

68. Oladosu, Y.; Rafii, M.Y.; Samuel, C.; Fatai, A.; Magaji, U.; Kareem, I.; Kamarudin, Z.S.; Muhammad, I.I.; Kolapo, K. Drought Resistance in Rice from Conventional to Molecular Breeding: A Review. Int. J. Mol. Sci. 2019, 20, 3519. [CrossRef] [PubMed]

69. Liu, S.; Qin, F. Genetic dissection of maize drought tolerance for trait improvement. Mol. Breed. 2021, 41, 8. [CrossRef]

70. Kopittke, P.N.; Menzies, P.; Wang, B.A.; McKenna, E. Lombi Soil and the intensification of agriculture for global food security. Environ. Int. 2019, 132, 105078. [PubMed]

71. Munns, R.; Gilliham, M. Salinity tolerance of crops-what is the cost? New Phytol. 2015, 208, 668-673. [CrossRef]

72. Zhao, C.; Zhang, C.H.; Song, J.K.; Zhu, S. Shabala. Mechanisms of plant responses and adaptation to soil salinity. Innovation 2020, 1,100017

73. Parihar, P.; Singh, S.S.; Singh, R.; Singh, V.P.; Prasad, S.M. Effect of salinity stress on plants and its tolerance strategies: A review. Environ. Sci. Pollut. Res. 2015, 22, 4056-4075. [CrossRef]

74. İbrahimova, U.; Kumari, P.; Yadav, S.; Rastogi, A.; Antala, M.; Suleymanova, Z.; Zivcak, M.; Arif, T.-U.; Hussain, S.; Abdelhamid, M.; et al. Progress in understanding salt stress response in plants using biotechnological tools. J. Biotechnol. 2021, 329, 180-191. [CrossRef]

75. Liang, W.; Ma, X.; Wan, P.; Liu, L. Plant salt-tolerance mechanism: A review. Biochem. Biophys. Res. Commun. 2018, 495, 286-291. [CrossRef]

76. Ashraf, M.H.P.J.C.; Harris, P.J. Photosynthesis under stressful environments: An overview. Photosynthetica 2013, 51, 163-190. [CrossRef]

77. Negrão, S.; Schmöckel, S.M.; Tester, M. Evaluating physiological responses of plants to salinity stress. Ann. Bot. 2017, 119, 1-11. [CrossRef]

78. Duarte, B.; Sleimi, N.; Caçador, I. Biophysical and biochemical constraints imposed by salt stress: Learning from halophytes Front. Plant Sci. 2014, 5, 746. [CrossRef] [PubMed]

79. Ventura, Y.; Eshel, A.; Pasternak, D.; Sagi, M. The development of halophyte based agriculture: Past and present. Ann. Bot. 2015, 115, 529-540. [CrossRef]

80. Acosta-Motos, J.R.; Ortuño, M.F.; Bernal-Vicente, A.; Diaz-Vivancos, P.; Sanchez-Blanco, M.J.; Hernandez, J.A. Plant responses to salt stress: Adaptive mechanisms. Agronomy 2017, 7, 18. [CrossRef]

81. Li, P.; Yang, X.; Wang, H.; Pan, T.; Wang, Y.; Xu, Y.; Xu, C.; Yang, Z. Genetic control of root plasticity in response to salt stress in maize. Theor. Appl. Genet. 2021, 134, 1475-1492. [CrossRef] [PubMed]

82. Pierik, R.; Testerink, C. The art of being flexible: How to escape from shade; salt; and drought. Plant Physiol. 2014, 166, 5-22. [CrossRef] [PubMed]

83. Chun, H.J.; Baek, D.; Cho, H.M.; Jung, H.S.; Jeong, M.S.; Jung, W.-H.; Choi, C.W.; Lee, S.H.; Jin, B.J.; Park, M.S.; et al. Metabolic adjustment of Arabidopsis root suspension cells during adaptation to salt stress and mitotic stress memory. Plant Cell Physiol. 2019, 60, 612-625. [CrossRef] [PubMed]

84. Cassaniti, C.; Leonardi, C.; Flowers, T.J. The effects of sodium chloride ornamental shrubs. Sci. Hortic. 2009, 122, 586-593 [CrossRef]

85. Kumar, S.; Li, G.; Yang, J.; Huang, X.; Ji, Q.; Liu, Z.; Ke, W.; Hou, H. Effect of Salt Stress on Growth; Physiological Parameters; and Ionic Concentration of Water Dropwort (Oenanthe javanica) Cultivars. Front. Plant Sci. 2021, 12, 660409. [CrossRef]

86. Rahneshan, Z.; Nasibi, F.; Moghadam, A.A. Effects of salinity stress on some growth; physiological; biochemical parameters and nutrients in two pistachio (Pistacia vera L.) rootstocks. J. Plant Interact. 2018, 13, 73-82. [CrossRef] 
87. dos Santos, T.B.; Budzinski, I.G.; Marur, C.J.; Petkowicz, C.L.; Pereira, L.F.; Vieira, L.G. Expression of three galactinol synthase isoforms in Coffea arabica L. and accumulation of raffinose and stachyose in response to abiotic stresses. Plant Physiol. Biochem. 2011, 49, 441-448. [CrossRef]

88. Abid, M.; Zhang, Y.J.; Li, Z.; Bai, D.F.; Zhong, Y.P.; Fang, J.B. Effect of salt stress on growth; physiological and biochemical characters of four kiwifruit genotypes. Sci. Hortic. 2020, 271, 109473. [CrossRef]

89. Molazem, D.; Azimi, J. Morpho-Physiological Characterization in Eight Varieties of Maize (Zea mays L.) under Soil Salinity. Pol. J. Environ. Stud. 2015, 24, 2537-2542. [CrossRef]

90. Phang, T.H.; Shao, G.; Lam, H.M. Salt tolerance in soybean. J. Integr. Plant Biol. 2008, 50, 1196-1212. [CrossRef] [PubMed]

91. Płażek, A.; Tatrzańska, M.; Maciejewski, M.; Kościelniak, J.; Gondek, K.; Bojarczuk, J.; Dubert, F. Investigation of the salt tolerance of new Polish bread and durum wheat cultivars. Acta Physiologiae Plantarum 2013, 35, 2513-2523. [CrossRef]

92. Zouari, M.; Ahmed, C.B.; Elloumi, N.; Bellassoued, K.; Delmail, D.; Labrousse, P.; Abdallah, F.B.; Rouina, B.B. Impact of proline application on cadmium accumulation; mineral nutrition and enzymatic antioxidant defense system of Olea europaea L. cv Chemlali exposed to cadmium stress. Ecotoxicol. Environ. Saf. 2016, 128, 195-205. [CrossRef] [PubMed]

93. Lima, R.B.; dos Santos, T.B.; Vieira, L.G.E.; Ferrarese, M.D.L.L.; Ferrarese-Filho, O.; Donatti, L.; de Oliveira Petkowicz, C.L. Salt stress alters the cell wall polysaccharides and anatomy of coffee (Coffea arabica L.) leaf cells. Carbohydr. Polym. 2014, 112, 686-694. [CrossRef]

94. Mbarki, S.; Sytar, O.; Cerda, A.; Zivcak, M.; Rastogi, A.; He, X.; Zoghlami, A.; Abdelly, C.; Brestic, M. Strategies to mitigate the salt stress effects on photosynthetic apparatus and productivity of crop plants. In Salinity Responses and Tolerance in Plants; Springer: Cham, Switzerland, 2018; Volume 1, pp. 85-136.

95. Hnilickova, H.; Hnilicka, F.; Martinkova, J.; Kraus, K. Effects of Salt Stress on Water Status; Photosynthesis and Chlorophyll Fluorescence of Rocket. Plant Soil Environ. 2017, 63, 362-367.

96. Mehta, P.; Jajoo, A.; Mathur, S.; Bharti, S. Chlorophyll a Fluorescence Study Revealing Effects of High Salt Stress on Photosystem II in Wheat Leaves. Plant Physiol. Biochem. 2010, 48, 16-20. [CrossRef]

97. Kalaji, H.M.; Rastogi, A.; Zivcak, M.; Brestic, M.; Daszkowska-Golec, A.; Sitko, K.; Alsharafa, K.Y.; Lotfi, R.; Stypiński, P.; Samborska, I.A.; et al. Prompt Chlorophyll Fluorescence as a Tool for Crop Phenotyping: An Example of Barley Landraces Exposed to Various Abiotic Stress Factors. Photosynthetica 2018, 56, 953-961. [CrossRef]

98. Wang, X.; Wang, W.; Huang, J.; Peng, S.; Xiong, D. Diffusional conductance to $\mathrm{CO}_{2}$ is the key limitation to photosynthesis in salt-stressed leaves of rice (Oryza sativa). Physiol. Plant 2018, 163, 45-58. [CrossRef]

99. Hussain, N.; Ghaffar, A.; Zafar, Z.U.; Javed, M.; Shah, K.H.; Noreen, S.; Manzoor, H.; Iqbal, M.; Hassan, I.F.Z.; Bano, H.; et al. Identification of novel source of salt tolerance in local bread wheat germplasm using morpho-physiological and biochemical attributes. Sci. Rep. 2021, 11, 10854. [CrossRef] [PubMed]

100. Hnilickova, H.; Kraus, K.; Vachova, P.; Hnilicka, F. Salinity Stress Affects Photosynthesis; Malondialdehyde Formation; and Proline Content in Portulaca oleracea L. Plants 2021, 10, 845. [CrossRef] [PubMed]

101. Chutipaijit, S.; Cha-um, S.; Sompornpailin, K. High contents of proline and anthocyanin increase protective response to salinity in Oryza sativa L. spp. 'indica'. Aust. J. Crop Sci. 2011, 5, 1191-1198.

102. Amirjani, M.R. Effect of salinity stress on growth; sugar content; pigments and enzyme activity of rice. Int. J. Bot. Stud. 2011, 7, 73-81. [CrossRef]

103. Hernández, J.A.; Jiménez, A.; Mullineaux, P.M.; Sevilla, F. Tolerance of pea (Pisum sativum L.) to long-term salt stress is associated with induction of antioxidant defenses. Plant Cell Environ. 2000, 23, 853-862. [CrossRef]

104. Sgherri, C.; Pinzino, C.; Quartacci, M.F. Reactive oxygen species and photosynthetic functioning: Past and present. In Reactive Oxygen Species in Plants: Boon or Bane-Revisiting the Role of ROS; Wiley: Chichester, UK, 2018; pp. 137-155.

105. AbdElgawad, H.; Zinta, G.; Hegab, M.M.; Pandey, R.; Asard, H.; Abuelsoud, W. High salinity induces different oxidative stress and antioxidant responses in maize seedlings organs. Front. Plant Sci. 2016, 7, 276. [CrossRef]

106. Gill, S.S.; Tuteja, N. Reactive oxygen species and antioxidant machinery in abiotic stress tolerance in crop plants. Plant Physiol. Biochem. 2010, 48, 909-930. [CrossRef]

107. Rakhmankulova, Z.F.; Shuyskaya, E.V.; Shcherbakov, A.V.; Fedyaev, V.V.; Biktimerova, G.Y.; Khafisova, R.R.; Usmanov, I.Y. Content of proline and flavonoids in the shoots of halophytes inhabiting the South Urals. Russ. J. Plant Physiol. 2015, 62, 71-79. [CrossRef]

108. Giordano, M.; Petropoulos, S.A.; Rouphael, Y. Response and defence mechanisms of vegetable crops against drought, heat and salinity stress. Agriculture 2021, 11, 463. [CrossRef]

109. Chung, Y.S.; Kim, K.S.; Hamayun, M.; Kim, Y. Silicon confers soybean resistance to salinity stress through regulation of reactive oxygen and reactive nitrogen species. Front. Plant Sci. 2020, 10, 1725. [CrossRef]

110. Abdelaziz, M.E.; Abdelsattar, M.; Abdeldaym, E.A.; Atia, M.A.; Mahmoud, A.W.M.; Saad, M.M.; Hirt, H. Piriformospora indica alters $\mathrm{Na}+/ \mathrm{K}+$ homeostasis, antioxidant enzymes and LeNHX1 expression of greenhouse tomato grown under salt stress. Sci. Hortic. 2019, 256, 108532. [CrossRef]

111. Gengmao, Z.; Shihui, L.; Xing, S.; Yizhou, W.; Zipan, C. The role of silicon in physiology of the medicinal plant (Lonicera japonica L.) under salt stress. Sci. Rep. 2015, 5, 12696. [CrossRef] [PubMed] 
112. Jahantigh, O.; Najafi, F.; Badi, H.N.; Khavari-Nejad, R.A.; Sanjarian, F. Changes in antioxidant enzymes activities and proline, total phenol and anthocyanine contents in Hyssopus officinalis L. plants under salt stress. Acta Biol. Hung. 2016, 67, 195-204. [CrossRef] [PubMed]

113. Bonacina, C.; Trevizan, C.B.; Stracieri, J.; dos Santos, T.B.; Goncalves, J.E.; Gazim, Z.C.; Souza, S.G.H. Changes in growth, oxidative metabolism and essential oil composition of lemon balm ('Melissa officinalis' L.) subjected to salt stress. Aust. J. Crop. Sci. 2017, 11, 1665-1674. [CrossRef]

114. Bonacina, C.; Cruz, R.M.S.; Nascimento, A.B.; Barbosa, L.N.; Gonçalves, J.E.; Gazim, Z.C.; Magalhães, H.M.; Souza, S.G.H. Salinity modulates growth, oxidative metabolism, and essential oil profile in Curcuma longa L. (Zingiberaceae) rhizomes. S. Afr. J. Bot. 2022, 146, 1-11. [CrossRef]

115. Qu, C.; Liu, C.; Gong, X.; Li, C.; Hong, M.; Wang, L.; Hong, F. Impairment of maize seedling photosynthesis caused by a combination of potassium deficiency and salt stress. Environ. Exp. Bot. 2012, 75, 134-141. [CrossRef]

116. Li, S.; Li, Y.; He, X.; Li, Q.; Liu, B.; Ai, X.; Zhang, D. Response of water balance and nitrogen assimilation in cucumber seedlings to $\mathrm{CO}_{2}$ enrichment and salt stress. Plant Physiol. Biochem. 2019, 139, 256-263. [CrossRef]

117. Singh, R.K.; Prasad, A.; Muthamilarasan, M.; Parida, S.K.; Prasad, M. Breeding and biotechnological interventions for trait improvement: Status and prospects. Planta 2020, 252, 54. [CrossRef]

118. Nakhla, W.R.; Sun, W.; Fan, K.; Yang, K.; Zhang, C.; Yu, S. Identification of QTLs for Salt Tolerance at the Germination and Seedling Stages in Rice. Plants 2021, 10, 428. [CrossRef]

119. Cho, K.H.; Kim, M.Y.; Kwon, H.; Yang, X.; Lee, S.H. Novel QTL identification and candidate gene analysis for enhancing salt tolerance in soybean (Glycine max (L.) Merr.). Plant Sci. 2021, 313, 111085. [CrossRef]

120. Lopez, C.; Orazaly, M.; Mozzoni, L.; Korth, K.L.; Chen, P. Quantitative trait loci for salt tolerance in soybean. J. Crop. Improv. 2018, 32, 766-780. [CrossRef]

121. Luo, M.; Zhang, Y.; Chen, K.; Kong, M.; Song, W.; Lu, B.; Shi, Y.; Zhao, Y.; Zhao, J. Mapping of quantitative trait loci for seedling salt tolerance in maize. Mol. Breed. 2019, 39, 64. [CrossRef]

122. Singh, R.K.; Kota, S.; Flowers, T.J. Salt tolerance in rice: Seedling and reproductive stage QTL mapping come of age. Theor. Appl. Genet. 2021, 134, 3495-3533. [CrossRef] [PubMed]

123. Ahmadizadeh, M.; Babaeian-Jelodar, N.; Mohammadi-Nejad, G.; Singh, R.K. High-density linkage mapping for agronomic and physiological traits of rice (Oryza sativa L.) under reproductive-stage salt stress. J. Genet. 2021, 100, 51. [CrossRef] [PubMed]

124. Zhang, A.; Liu, Y.; Wang, F.; Li, T.; Chen, Z.; Kong, D.; Bi, J.; Zhang, F.; Luo, X.; Wang, J.; et al. Enhanced Rice Salinity Tolerance via CRISPR/Cas9-Targeted Mutagenesis of the OsRR22 Gene. Mol. Breed. 2019, 39, 47. [CrossRef]

125. Kumar, V.V.S.; Verma, R.K.; Yadav, S.K.; Yadav, P.; Watts, A.; Rao, M.V.; Chinnusamy, V. CRISPR-Cas9 Mediated Genome Editing of Drought and Salt Tolerance (OsDST) Gene in Indica Mega Rice Cultivar MTU1010. Physiol. Mol. Biol. Plants 2020, 26, 1099-1110. [CrossRef]

126. Tran, M.T.; Doan, D.T.H.; Kim, J.; Song, Y.J.; Sung, Y.W.; Das, S.; Kim, E.-J.; Son, G.H.; Kim, S.H.; Van Vu, T.; et al. CRISPR/Cas9Based Precise Excision of SlHyPRP1 Domain(s) to Obtain Salt Stress-Tolerant Tomato. Plant Cell Rep. 2021, 40, 999-1011. [CrossRef]

127. Roy, S.J.; Negrao, S.; Tester, M. Salt resistant crop plants. Curr. Opin. Biotechnol. 2014, 26, 115-124. [CrossRef]

128. Huang, Y.; Guan, C.; Liu, Y.; Chen, B.; Yuan, S.; Cui, X.; Zhang, Y.; Yang, F. Enhanced growth performance and salinity tolerance in transgenic switchgrass via overexpressing vacuolar $\mathrm{Na}^{+}\left(\mathrm{K}^{+}\right) / \mathrm{H}^{+}$antiporter gene (PvNHX1). Front. Plant Sci. 2017, 8, 1-13. [CrossRef]

129. Xu, C.; Luo, M.; Sun, X.; Yan, J.; Shi, H.; Yan, H.; Yan, R.; Wang, S.; Tang, W.; Zhou, Y.; et al. SiMYB19 from Foxtail Millet (Setaria italica) Confers Transgenic Rice Tolerance to High Salt Stress in the Field. Int. J. Mol. Sci. 2022, 23, 756. [CrossRef]

130. Li, M.; Chen, R.; Jiang, Q.; Sun, X.; Zhang, H.; Hu, Z. GmNAC06, a NAC domain transcription factor enhances salt stress tolerance in soybean. Plant Mol. Biol. 2021, 105, 333-345. [CrossRef] [PubMed]

131. Kaushal, N.; Bhandari, K.; Siddique, K.H.; Nayyar, H. Food crops face rising temperatures: An overview of responses, adaptive mechanisms, and approaches to improve heat tolerance. Cogent Food Agric. 2016, 2, 1134380. [CrossRef]

132. Qu, A.-L.; Ding, Y.-F.; Jiang, Q.; Zhu, C. Molecular mechanisms of the plant heat stress response. Biochem. Biophys. Res. Commun. 2013, 432, 203-207. [CrossRef]

133. Singh, A.; Kumar, A.; Yadav, S.; Singh, I.K. Reactive oxygen species-mediated signaling during abiotic stress. Plant Gene 2019, 18, 100-173. [CrossRef]

134. Lesk, C.; Rowhani, P.; Ramankutty, N. Influence of extreme weather disasters on global crop production. Nature 2016, 529, 84. [CrossRef]

135. Singsaas, E.L.; Laporte, M.M.; Shi, J.-Z.; Monson, R.K.; Bowling, D.R.; Johnson, K.; Lerdau, M.; Jasentuliytana, A.; Sharkey, T.D. Kinetics of leaf temperature fluctuation affect isoprene emission from red oak (Quercus rubra) leaves. Tree Physiol. 1999, 19, 917-924. [CrossRef]

136. Ahanger, M.A.; Akram, N.A.; Ashraf, M.; Alyemeni, M.N.; Wijaya, L.; Ahmad, P. Plant responses to environmental stresses-From gene to biotechnology. AoB Plants 2017, 9, 1-17. [CrossRef]

137. Li, N.; Euring, D.; Cha, J.Y.; Lin, Z.; Lu, M.; Huang, L.J.; Kim, W.Y. Plant hormone-mediated regulation of heat tolerance in response to global climate change. Front. Plant Sci. 2021, 11, 2318. [CrossRef] 
138. Sicher, R.C.; Timlin, D.; Bailey, B. Responses of growth and primary metabolism of water-stressed barley roots to rehydration. J. Plant Physiol. 2012, 169, 686-695. [CrossRef]

139. Goufo, P.; Moutinho-Pereira, J.M.; Jorge, T.F.; Correia, C.M.; Oliveira, M.R.; Rosa, E.A.S.; António, C.; Trindade, H. Cowpea (Vigna unguiculata L. Walp.) Metabolomics: Osmoprotection as a Physiological Strategy for Drought Stress Resistance and Improved Yield. Front. Plant Sci. 2017, 8, 586. [CrossRef]

140. Lima, R.B.; dos Santos, T.B.; Vieira, L.G.E.; de Lourdes Lúcio Ferrarese, M.; Ferrarese-Filho, O.; Donatti, L.; Boeger, M.R.T.; de Oliveira Petkowicz, C.L. Heat stress causes alterations in the cell-wall polymers and anatomy of coffee leaves (Coffea arabica L.) Carbohydr. Polym. 2013, 93, 135-143. [CrossRef] [PubMed]

141. Wahid, A. Physiological Implications of Metabolite Biosynthesis for Net Assimilation and Heat-Stress Tolerance of Sugarcane (Saccharum officinarum) Sprouts. J. Plant Res. 2007, 120, 219-228. [CrossRef] [PubMed]

142. Farooq, M.; Wahid, A.; Kobayashi, N.; Fujita, D.; Basra, S.M.A. Plant drought stress: Effects, mechanisms and management. Agron. Sustain. Agric. 2009, 29, 153-188.

143. Zandalinas, S.I.; Balfagón, D.; Arbona, V.; Gómez-Cadenas, A.; Inupakutika, M.A.; Mittler, R. ABA is required for the accumulation of APX1 and MBF1c during a combination of water deficit and heat stress. J. Exp. Bot. 2016, 67, 5381-5390. [CrossRef] [PubMed]

144. Wang, X.; Hou, L.; Lu, Y.; Wu, B.; Gong, X.; Liu, M.; Wang, J.; Sun, Q.; Vierling, E.; Xu, S. Metabolic adaptation of wheat grain contributes to a stable filling rate under heat stress. J. Exp. Bot. 2018, 69, 5531-5545. [CrossRef] [PubMed]

145. Raza, A. Metabolomics: A systems biology approach for enhancing heat stress tolerance in plants. Plant Cell Rep. 2020, 1-23. [CrossRef]

146. Yamori, W.; Hikosaka, K.; Way, D.A. Temperature response of photosynthesis in C3, C4, and CAM plants: Temperature acclimation and temperature adaptation. Photosynth. Res. 2014, 119, 101-117. [CrossRef]

147. Betti, M.; Bauwe, H.; Busch, F.; Fernie, A.R.; Keech, O.; Levey, M.; Ort, D.R.; Parry, M.A.J.; Sage, R.; Timm, S.; et al. Manipulating photorespiration to increase plant productivity: Recent advances and perspectives for crop improvement. J. Exp. Bot. 2016, 67, 2977-2988. [CrossRef]

148. Ohama, N.; Sato, H.; Shinozaki, K.; Yamaguchi-Shinozaki, K. Transcriptional regulatory network of plant heat stress response Trends Plant Sci. 2017, 22, 53-65. [CrossRef]

149. Stief, A.; Altmann, S.; Hoffmann, K.; Pant, B.D.; Scheible, W.-R.; Bäurle, I. Arabidopsis miR156 Regulates Tolerance to Recurring Environmental Stress through SPL Transcription Factors. Plant Cell 2014, 26, 1792-1807. [CrossRef]

150. Liu, J.; Feng, L.; Li, J.; He, Z. Genetic and epigenetic control of plant heat responses. Front. Plant Sci. 2015, 6, 267. [CrossRef] [PubMed]

151. Wang, Q.; Serban, A.J.; Wachter, R.M.; Moerner, W.E. Single-Molecule Diffusometry Reveals the Nucleotide-Dependent Oligomerization Pathways of Nicotiana Tabacum Rubisco Activase. J. Chem. Phys. 2018, 148, 123319. [CrossRef] [PubMed]

152. Sun, A.-Z.; Guo, F.-Q. Chloroplast Retrograde Regulation of Heat Stress Responses in Plants. Front. Plant Sci. 2016, 7, 398 [CrossRef] [PubMed]

153. Todaka, D.; Nakashima, K.; Shinozaki, K.; Yamaguchi-Shinozaki, K. Toward understanding transcriptional regulatory networks in abiotic stress responses and tolerance in rice. Rice J. 2012, 5, 6. [CrossRef]

154. Moustafa, K.; Abuqamar, S.; Jarrar, M.; Al-Rajab, A.J.; Trémouillaux-Guiller, J. MAPK cascades and major abiotic stresses. Plant Cell Rep. 2014, 33, 1217-1225. [CrossRef]

155. Guo, W.; Zhang, J.; Zhang, N.; Xin, M.; Peng, H.; Hu, Z.; Ni, Z.; Du, J. The Wheat NAC Transcription Factor TaNAC2L Is Regulated at the Transcriptional and Post-Translational Levels and Promotes Heat Stress Tolerance in Transgenic Arabidopsis. PLoS ONE 2015, 10, e0135667. [CrossRef]

156. Liu, Z.-M.; Yue, M.-M.; Yang, D.-Y.; Zhu, S.-B.; Ma, N.-N.; Meng, Q.-W. Over-Expression of SlJA2 Decreased Heat Tolerance of Transgenic Tobacco Plants via Salicylic Acid Pathway. Plant Cell Rep. 2017, 36, 529-542. [CrossRef]

157. Fahad, S.; Bajwa, A.A.; Nazir, U.; Anjum, S.A.; Farooq, A.; Zohaib, A.; Sadia, S.; Nasim, W.; Adkins, S.; Saud, S.; et al. Crop Production under Drought and Heat Stress: Plant Responses and Management Options. Front. Plant Sci. 2017, 8, 1147. [CrossRef]

158. Wang, R.; Zhang, Y.; Wang, C.; Wang, Y.C.; Wang, L.Q. ThNAC12 from Tamarix hispida directly regulates ThPIP2; 5 to enhance salt tolerance by modulating reactive oxygen species. Plant Physiol. Biochem. 2021, 163, 27-35. [CrossRef]

159. Talukder, S.K.; Babar, M.A.; Vijayalakshmi, K.; Poland, J.; Prasad, P.V.V.; Bowden, R.; Fritz, A. Mapping QTL for the traits associated with heat tolerance in wheat (Triticum aestivum L.). BMC Genet. 2014, 15, 97. [CrossRef]

160. Acuña-Galindo, M.A.; Mason, R.E.; Subramanian, N.K.; Hays, D.B. Meta-Analysis of Wheat QTL Regions Associated with Adaptation to Drought and Heat Stress. Crop Sci. 2015, 55, 477-492. [CrossRef]

161. Sharma, D.K.; Torp, A.M.; Rosenqvist, E.; Ottosen, C.O.; Andersen, S.B. QTLs and potential candidate genes for heat stress tolerance identified from the mapping populations specifically segregating for F v/F $\mathrm{m}$ in wheat. Front. Plant Sci. 2017, 8, 1668. [CrossRef] [PubMed]

162. Bhusal, N.; Sarial, A.K.; Sharma, P.; Sareen, S. Mapping QTLs for grain yield components in wheat under heat stress. PLoS ONE 2017, 12, e0189594. [CrossRef]

163. Hassan, F.S.C.; Solouki, M.; Fakheri, B.A.; Nezhad, N.M.; Masoudi, B. Mapping QTLs for physiological and biochemical traits related to grain yield under control and terminal heat stress conditions in bread wheat (Triticum aestivum L.). Physiol. Mol. Biol. Plants 2018, 24, 1231-1243. [CrossRef] [PubMed] 
164. Gous, P.W.; Hickey, L.; Christopher, J.T.; Franckowiak, J.; Fox, G.P. Discovery of QTL for stay-green and heat-stress in barley (Hordeum vulgare) grown under simulated abiotic stress conditions. Euphytica 2016, 207, 305-317. [CrossRef]

165. Kushwah, A.; Bhatia, D.; Singh, I.; Thudi, M.; Singh, G.; Bindra, S.; Vij, S.; Gill, B.; Bharadwaj, C.; Singh, S. Identification of stable heat tolerance QTLs using inter-specific recombinant inbred line population derived from GPF 2 and ILWC 292. PLoS ONE 2021, 16, e0254957. [CrossRef]

166. Du, L.; Cai, C.; Wu, S.; Zhang, F.; Hou, S.; Guo, W. Evaluation and exploration of favorable QTL alleles for salt stress related traits in cotton cultivars (G. hirsutum L.). PLoS ONE 2016, 11, e0151076. [CrossRef]

167. Majeed, S.; Rana, I.A.; Atif, R.M.; Zulfiqar, A.; Hinze, L.; Azhar, M.T. Role of SNPs in determining QTLs for major traits in cotton. J. Cotton Res. 2019, 2, 5. [CrossRef]

168. Driedonks, N.; Wolters-Arts, M.; Huber, H.; de Boer, G.J.; Vriezen, W.; Mariani, C.; Rieu, I. Exploring the natural variation for reproductive thermotolerance in wild tomato species. Euphytica 2018, 214, 67. [CrossRef]

169. Bineau, E.; Diouf, I.; Carretero, Y.; Duboscq, R.; Bitton, F.; Djari, A.; Zouine, M.; Causse, M. Genetic diversity of tomato response to heat stress at the QTL and transcriptome levels. Plant J. 2021, 107, 1213-1227. [CrossRef]

170. Ravikiran, K.; Krishnan, S.G.; Vinod, K.; Dhawan, G.; Dwivedi, P.; Kumar, P.; Bansal, V.P.; Nagarajan, M.; Bhowmick, P.K.; Ellur, R. A trait specific QTL survey identifies NL44, a NERICA cultivar as a novel source for reproductive stage heat stress tolerance in rice. Plant Physiol. Rep. 2020, 25, 664-676. [CrossRef]

171. Majeed, S.; Rana, I.A.; Mubarik, M.S.; Atif, R.M.; Yang, S.-H.; Chung, G.; Jia, Y.; Du, X.; Hinze, L.; Azhar, M.T. Heat Stress in Cotton: A Review on Predicted and Unpredicted Growth-Yield Anomalies and Mitigating Breeding Strategies. Agronomy 2021, 11, 1825. [CrossRef]

172. Ashkani, S.; Rafii, M.Y.; Shabanimofrad, M.; Miah, G.; Sahebi, M.; Azizi, P.; Tanweer, F.A.; Akhtar, M.S.; Nasehi, A. Molecular breeding strategy and challenges towards improvement of blast disease resistance in rice crop. Front. Plant Sci. 2015, 6, 886. [CrossRef] [PubMed]

173. Templer, S.E.; Ammon, A.; Pscheidt, D.; Ciobotea, O.; Schuy, C.; McCollum, C.; Sonnewald, U.; Hanemann, A.; Förster, J.; Ordon, F.; et al. Metabolite profiling of barley flag leaves under drought and combined heat and drought stress reveals metabolic QTLs for metabolites associated with antioxidant defense. J. Exp. Bot. 2017, 68, 1697-1713. [CrossRef] [PubMed]

174. Thomason, K.; Babar, M.A.; Erickson, J.E.; Mulvaney, M.; Beecher, C.; MacDonald, G. Comparative physiological and metabolomics analysis of wheat (Triticum aestivum L.) following post-anthesis heat stress. PLoS ONE 2018, 13, e0197919. [CrossRef] [PubMed]

175. Lawas, L.M.F.; Li, X.; Erban, A.; Kopka, J.; Jagadish, S.K.; Zuther, E.; Hincha, D.K. Metabolic responses of rice cultivars with different tolerance to combined drought and heat stress under field conditions. Gigascience 2019, 8, 50. [CrossRef] [PubMed]

176. Dhatt, B.K.; Abshire, N.; Paul, P.; Hasanthika, K.; Sandhu, J.; Zhang, Q.; Obata, T.; Walia, H. Metabolic dynamics of developing rice seeds under high night-time temperature stress. Front. Plant Sci. 2019, 10, 1443. [CrossRef]

177. Wang, L.; Ma, K.-B.; Lu, Z.-G.; Ren, S.-X.; Jiang, H.-R.; Cui, J.-W.; Chen, G.; Teng, N.-J.; Lam, H.-M.; Jin, B. Differential physiological, transcriptomic and metabolomic responses of Arabidopsis leaves under prolonged warming and heat shock. BMC Plant Biol. 2020, 20, 86. [CrossRef]

178. Wei, S.; Yang, X.; Huo, G.; Ge, G.; Liu, H.; Luo, L.; Hu, J.; Huang, D.; Long, P. Distinct metabolome changes during seed germination of lettuce (Lactuca sativa L.) in response to thermal stress as revealed by untargeted metabolomics analysis. Int. J. Mol. Sci. 2020, 21, 1481. [CrossRef]

179. Abdelrahman, M.; Burritt, D.J.; Gupta, A.; Tsujimoto, H.; Tran, L.-S.P. Heat stress effects on source-sink relationships and metabolome dynamics in wheat. J. Exp. Bot. 2020, 71, 543-554. [CrossRef]

180. Bhatnagar-Mathur, P.; Vadez, V.; Sharma, K.K. Transgenic approaches for abiotic stress tolerance in plants: Retrospect and prospects. Plant Cell Rep. 2008, 27, 411-424. [CrossRef] [PubMed]

181. Kaur, R.; Sinha, K.; Bhunia, R.K. Can Wheat Survive in Heat? Assembling Tools towards Successful Development of Heat Stress Tolerance in Triticum Aestivum, L. Mol. Biol. Rep. 2019, 46, 2577-2593. [CrossRef] [PubMed]

182. Dangol, S.D.; Naeem, M.; Azimi, M.H.; Yasmeen, A.; Caliskan, M.E.; Bakhsh, A. Genetic Engineering of Solanum tuberosum L. to Enhance Resistance Against Abiotic Stresses: A Review. J. Sci. 2018, 1, 1-10.

183. Batcho, A.A.; Sarwar, M.B.; Rashid, B.; Hassan, S.; Husnain, T. Heat shock protein gene identified from Agave sisalana (As HSP70) confers heat stress tolerance in transgenic cotton (Gossypium hirsutum). Theor. Exp. Plant Physiol. 2021, 33, 141-156. [CrossRef]

184. Fragkostefanakis, S.; Roeth, S.; Schleiff, E.; Scharf, K. Prospects of Engineering Thermotolerance in Crops Through Modulation of Heat Stress Transcription Factor and Heat Shock Protein Networks. Plant Cell Environ. 2015, 38, 1881-1895. [CrossRef]

185. Bita, C.E.; Gerats, T. Plant tolerance to high temperature in a changing environment: Scientific fundamentals and production of heat stress-tolerant crops. Front. Plant Sci. 2013, 4, 273. [CrossRef]

186. Xu, Q.; Xu, X.; Shi, Y.; Xu, J.; Huang, B. Transgenic Tobacco Plants Overexpressing a Grass PpEXP1 Gene Exhibit Enhanced Tolerance to Heat Stress. PLoS ONE 2014, 9, e100792. [CrossRef]

187. dos Santos, T.B.; Vieira, L.G.E. Involvement of the galactinol synthase gene in abiotic and biotic stress responses: A review on current knowledge. Plant Gene 2020, 24, 100258. [CrossRef]

188. Mubarik, M.S.; Khan, S.H.; Ahmad, A.; Khan, Z.; Sajjad, M.; Khan, I.A. Disruption of Phytoene Desaturase Gene using Transient Expression of Cas9: gRNA Complex. Int. J. Agric. Biol. 2016, 18.

189. Yin, K.; Gao, C.; Qiu, J.L. Progress and prospects in plant genome editing. Nat. Plants 2017, 3, 17107. [CrossRef] 
190. Li, H.; Hu, T.; Amombo, E.; Fu, J. Genome-wide identification of heat stress-responsive small RNAs in tall fescue (Festuca arundinacea) by high-throughput sequencing. J. Plant Physiol. 2017, 213, 157-165. [CrossRef] [PubMed]

191. Li, Y.; Zhao, S.-L.; Li, J.-L.; Hu, X.-H.; Wang, H.; Cao, X.-L.; Xu, Y.-J.; Zhao, Z.-X.; Xiao, Z.-Y.; Yang, N. Osa-miR169 negatively regulates rice immunity against the blast fungus Magnaporthe oryzae. Front. Plant Sci. 2017, 8, 2. [CrossRef] [PubMed]

192. Bhogireddy, S.; Babu, M.S.; Swamy, K.N.; Vishnukiran, T.; Subrahmanyam, D.; Sarla, N.; Rao, P.R.; Mangrauthia, S.K. Expression Dynamics of Genes and microRNAs at Different Growth Stages and Heat Treatments in Contrasting High Temperature Responsive Rice Genotypes. J. Plant Growth Regul. 2022, 41, 74-91. [CrossRef]

193. Xu, J.; Hou, Q.M.; Khare, T.; Verma, S.K.; Kumar, V. Exploring miRNAs for developing climate-resilient crops: A perspective review. Sci. Total Environ. 2019, 653, 91-104. [CrossRef]

194. Zhang, P.; Wu, W.; Chen, Q.; Chen, M. Non-Coding RNAs and their Integrated Networks. J. Integr. Bioinform. 2019, 16, 1-2. [CrossRef] 